\title{
Biological Conversion of Synthesis Gas Culture Development
}

\section{Topical Report}

\author{
K.T. Klasson \\ R. Basu \\ E.R. Johnson \\ E.C. Clausen \\ J.L. Gaddy
}

March 1992

Work Performed Under Contract No.: DE-FG21-90MC27225

For

U.S. Department of Energy

Office of Fossil Energy

Morgantown Energy Technology Cente:

Morgantown, West Virginia

By

University of Arkansas

Department of Chemical Engineering

Fayetteville, Arkansas 


\section{DISCLAIMER}

This report was prepared as an account of work sponsored by an agency of the United States Government. Neither the United States Government nor any agency thereof, tior any of their employees makes any warranty, express or implied, or assumes any legal liability or responsibility for the accuracy, completeness or usefulness of any information, apparatus, product, or process disclosed, or represents that its use would not infringe privately owned rights. Reference herein to any specific commercial product, process, or service by trade name, trademark, manufacturer, or otherwise, does not necessarily constitute or imply its endorsement, recommendation, or favoring by the United States Government or any agency thereof. The views and opinions of authors expressed herein do not necessarily state or reflect those of the United States Government or any agency thereof.

This report has been reproduced directly from the best available copy.

Available to DOE and DOE contractors from the Office of Scientific and Technical Information, P.O. Box 62, Oak Ridge, TN 37831; prices available from (615)576-8401, FTS 626-8401.

Available to the public from the National Technical Information Service, U.S. Department of Commerce, 5285 Port Royal Rd., Springfield, VA 22161. 


\title{
Biological Conversion of Synthesis Gas
}

Culture Development

\author{
Topical Report
}

\author{
K.T. Klasson \\ R. Basu \\ E.R. Johnson \\ E.C. Clausen \\ J.L. Gaddy
}

Work Performed Under Contract No.: DE-FG21-90MC27225

\author{
For \\ U.S. Department of Energy \\ Office of Fossil Energy \\ Morgantown Energy Technology Center \\ P.O. Box 880 \\ Morgantown, West Virginia 26507-0880
By
University of Arkansas
Fayetteville, Arkansas $\mathbf{7 2 7 0 1}$ \\ Department of Chemical Engineering
}

March 1992 


\section{ACKNOWLEDGMENT}

Financial support for this work has been provided by the Morgantown Energy Technology Center, U. S. Department of Energy under grant number DEFG21-90MC27225. 


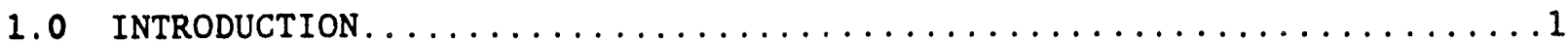

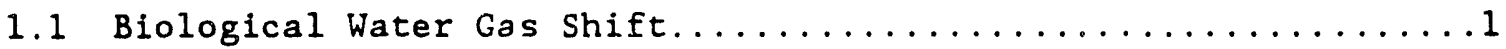

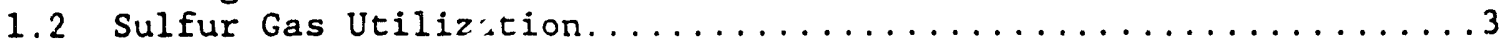

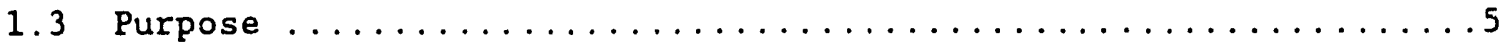

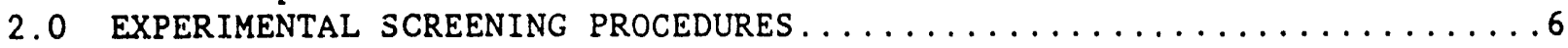

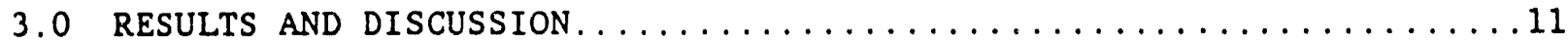

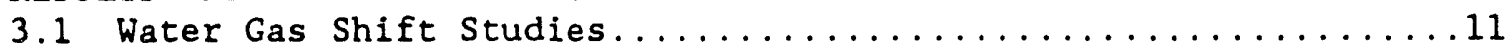

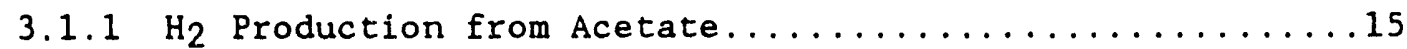

3.1.1.1 Bioreactor and Operating Conditions........16

3.1.1.2 Analytical Techniques..................

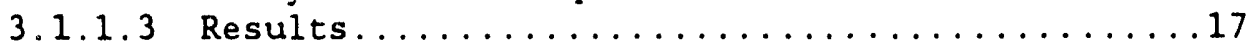

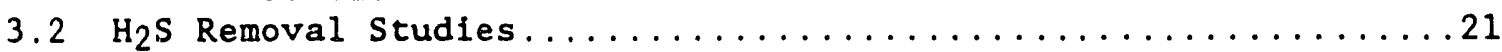

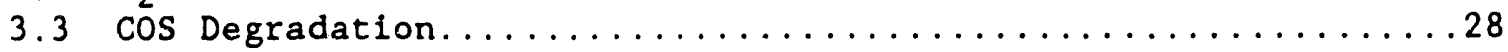

3.3.1 COS Degradation by Selected Co-Utilizing Bacteria......28

3.3.1.1 Co Conversion by Bacterial Cultures..........30

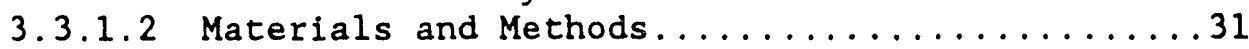

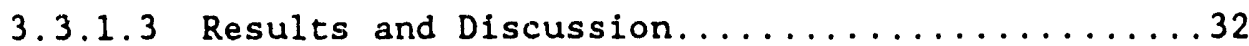

3.3 .2 Indirect $\cos$ Utilization by Chlorobia.............43

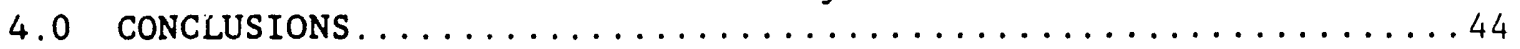

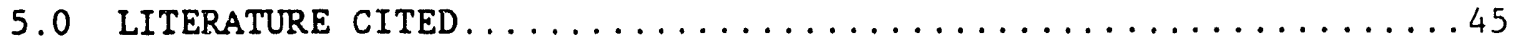




\section{LIST OF TABLES}

Page

1.1 Bacteria Capable of Carrying Out the Water Gas Shift Reaction.......2

1.2 Microorganisms Capable of Reducing $\mathrm{H}_{2} \mathrm{~S}$ to Elemental Sulfur.......4

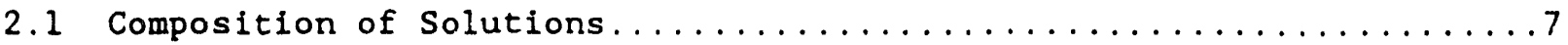

3.1 Initial Results of Water Gas Shift Reaction Studies $\ldots \ldots \ldots \ldots \ldots 12$

3.2 Modified Media Compositions.............................14

3.3 Results of Water Gas Shift Reactions Studies Using a Modified Medium.....................................

3.4 Medium Composition for $\mathrm{H}_{2}$ Production from Acetate..............

3.5 Initial Screening of Growth Conditions of $\mathrm{H}_{2} \mathrm{~S}$ Reducers...........29 
2.1 Cell Concentration Calibration Curve as a Function of Optical Density at $580 \mathrm{~nm}$ for $C$. thiosulfatophilum...............9

2.2 Cell Concentration Calibration Curve (Based Upon Chlorophyl Content) as a Function of Optical Density at $670 \mathrm{~nm}$ for C. thiosulfatophilum.......................... 10

$3.1 R$. rubrum Grown in the Presence of Glutamic Acid............18

$3.2 R$. rubrum Grown in the Presence of Glutamic and Acetic Acids ............................. 18

$3.3 R$. rubrum Grown in the Presence of $\mathrm{NH}_{4} \mathrm{Cl} \ldots \ldots \ldots \ldots \ldots$

$3.4 R$. rubrum Grown in the Presence of $\mathrm{NH}_{4} \mathrm{Cl}$ and Acetic Acid................................... 19

$3.5 R$. rubrum Grown in the Presence of Urea................20

3. $6 R$. rubrum Grown in the Presence of Urea and Acetic Acid..................................20

$3.7 R$. palustris Grown in the Presence of Glutamic Acid..........22

3.8 R. palustris Grown in the Presence of Glutamic and Acetic Acids..............................22

$3.9 R$. palustris Grown in the Presence of $\mathrm{NH}_{4} \mathrm{Cl} \ldots \ldots \ldots \ldots$

$3.10 R$. palustris Grown in the Presence of $\mathrm{NH}_{4} \mathrm{Cl}$ and Acetic Acid.....................................23

$3.11 R$. palustris Grown in the Presence of Urea................24

$3.12 R$. palustris Grown in the Presence of Urea and Acetic Acid.................................24

$3.13 R$. gelatinosus Grown in the Presence of Glutamic Acid.........25

$3.14 R$. gelatinosus Grown in the Presence of Glutamic and Acetic Acids ...............................25

$3.15 R$. gelatinosus Grown in the Presence of $\mathrm{NH}_{4} \mathrm{Cl} \ldots \ldots \ldots \ldots$

$3.16 R$. gelatinosus Grown in the Presence of $\mathrm{NH}_{4} \mathrm{Cl}$ and and Acetic Acid.............................26

$3.17 R$. gelatinosus Grown in the Presence of Urea..............

$3.18 R$. gelatinosus Grown in the Presence of Urea and Acetic Acid....27 
3.19 Co Uptake by $P$. productus in the Presence of $\cos \ldots \ldots \ldots \ldots$

3.20 Co Uptake by $E$. Iimosum in the Presence of COS ................

3.21 Co Uptake by $C$. 1 jungdahlii in the Presence of Cos.............

3.22 Co Uptake, by $R$. rubru.n in the Presence of Cos..................

3.23 COS Degradation by $P$. productus in Comparison to Medium Alone....37

3.24 COS Degradation by $E$. Iimosum in Comparison to

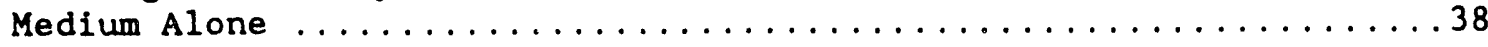

3.25 Cos Degradation by $C$. 1jungdahlii in Comparison to

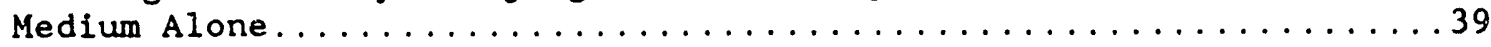

3.26 Cos Degradation my $R$. rubrum in Comparison to Medium Alone..............................40

3.27 Initial cos Utilization Rate as a Function of Initial CO Utilization Rate for $P$. productus, $E$. limosum and R.rubrum......42 


\subsection{INTRODUCTION}

\subsection{Biological Water Gas Shift}

Since very little has been published concerning the biological conversion of $\mathrm{CO}$ and water to $\mathrm{H}_{2}$ and $\mathrm{CO}_{2}$ according to the reaction of Equation (1.1), the initial screening process was based mostly upon previous work conducted in the University of Arkansas laboratories.

$$
\mathrm{CO}+\mathrm{H}_{2} \mathrm{O} \rightarrow \mathrm{H}_{2}+\mathrm{CO}_{2}
$$

In the past, two photosynthetic purple bacteria, Rhodospirillum rubrum and Rhodopseudomonas gelatinosa have been found to be capable of carrying out the water gas shift reaction (1). $R$. rubrum carries out the reaction both in the light and in the absence of light, but requires light for growth. $R$. gelatinosa, on the other hand, carries out the reaction in the dark and utilizes $C O$ as a carbon source for growth. Since both of these organisms were not originally identified as $\mathrm{H}_{2}$ producers in the literature, other bacteria with similar physiologies may also have $\mathrm{H}_{2}$ producing capabilities. Thus, bacteria with the following characteristics were sought as possible water gas shift biocatalysts:

1. be a purple non-sulfur photosynthetic bacterium in the Rhodospirillaceae family;

2. be capable of anaerobic growth in the light;

3. have an optimal temperature of $25-40^{\circ} \mathrm{C}$; and

4. show documented growth on simple substrates such as $\mathrm{CO}_{2}$ or acetate.

A list of bacteria satisfying the above criteria is shown in Table 1.1 (2 3). Based upon this list, three organisms (one from each genus) were selected for further study in the laboratory. The choice of organisms was based upon the ability of the organisms to use simple acids as substrates and 
Table 1.1

Bacteria Capable of Carrying Out the Biological

Water Gas Shift Reaction

\begin{tabular}{cc}
\hline ArCC $\# \quad$ Name & $\begin{array}{c}\text { Optimum } \\
\text { Temperature } \\
\left({ }^{\circ} \mathrm{C}\right)\end{array}$ \\
\hline
\end{tabular}

Rhodospirillum

25903

rubrum

$30-35$

25093

tenue $^{*}$

30

14031

molischianum

30

27871

photometricum

fulvum

30

Rhodopseudomonas

17001

palustris

$30-37$

195067

viridis

$25-30$

25092

acidophilia

$25-30$

17011

11166

17023

gelatinosa ${ }^{\star *}$

capsulata

30

sphaeroides

$25-30$

$25-30$

Rhodomicrobium

17100

vannielii

30

* - Also named - Rhodocyclus tenuis

** - Also named - Rhhodocyclus gelatinosus 
optimal growth conditions. Together with $R$. rubrum and $R$. gelatinosa (see Table 1.1), a representative collection of bacteria from the Rhodospirillaceae family was thus obtained. Each of the bacterial cultures was obtained from the American Type Culture Collection (Rockville, MD).

\subsection{Sulfur Gas Utilization}

A number of microbial processes for the oxidation of $\mathrm{H}_{2} \mathrm{~S}$ to $\mathrm{SO}_{4}^{2-}$ or elemental sulfur have been reported in the literature. The sulfur bacteria com $_{5}$ rise the phototropic and the chemolithotrophic bacteria, and the growth conditions may be anaerobic to aerobic. Based upon literature information $(2,4)$, the list presented in Table 1.2 was compiled with the following considerations in mind:

1. the bacterium must be capable of anaerobic growth and sulfide reduction;

2. the bacterium must show elemental sulfur accumulation outside the cell;

3. the bacterium must have an optimal temperature of 25 $40^{\circ} \mathrm{C}$; and

4. the bacterium must have shown documented growth on simple substrates such as $\mathrm{CO}_{2}$ or acetate.

of the five choices shown in Table 1.2 , only 2 were selected for further study at present: Chlorobium thiosulfatophilum and $C$. phaeobacteroides. $C$. thiosulfatophilum was obtained from ATCC (Rockville, MD) and $C$.

phaeobacteroides was kindly supplied by Dr. T. Bergstein, a visiting scientist at Washington University, St. Louis, MO. Ectothiorhodospira abdelmalekii was found not to be sultable for sulfur gas conversion due to its alkaline growth conditions at $\mathrm{pH} 8.5$ and high salinity (14-16\%) requirements (5). Thiobacillus denitrificans has also been initially rejected, not being 
phototrophic and mainly producing sulfate as the end product. Chloroflexus aurantiacus has not been selected for immediate study, but future plans may include studies of this organism. C. aurantiacus is capable of reducing $\mathrm{s}^{2}$ to elemental sulfur and does not produce substantial amounts of sulfate. However, only $50 \%$ of the initial sulfur present in the medium was accounted for as elemental sulfur in one study (6).

Table 1.2

Microorganisms Capable of Reducing $\mathrm{H}_{2} \mathrm{~S}$ to Elemental Sulfur

\begin{tabular}{|c|c|}
\hline ATCC 非 & Name \\
\hline \multirow[t]{2}{*}{35917} & Ectothiorhodospira abdelmalekii \\
\hline & Chlorobium \\
\hline 17092 & thiosulfatophilum \\
\hline N/A & phaeobacteroides \\
\hline 29362 & Chloroflexus aurantiacus \\
\hline 23642 & Thiobacillus denitroficans \\
\hline
\end{tabular}

In addition to the reduction of $\mathrm{H}_{2} \mathrm{~S}$, the removal of carbonyl sulfide $(\mathrm{COS})$, also present in the synthesis gas, is also desired. COS spontaneously undergoes a reaction with water to produce $\mathrm{H}_{2} \mathrm{~S}$ and $\mathrm{CO}_{2}$ (7) as described by the equation:

$$
\cos +\mathrm{H}_{2} \mathrm{O} \rightarrow \mathrm{H}_{2} \mathrm{~S}+\mathrm{CO}_{2}
$$


Thus, the removal of $\operatorname{COS}$ may be seen as a removal of $\mathrm{H}_{2} \mathrm{~S}$ produced according to Equation (1.2). It has also been proposed that CO-utilizing microorganisms may utilize $\cos$ due to their molecular similarities. Three cultures, Peptostreptoccus productus (ATCC 35244), Rhodospirillum rubrum (ATCC 25903) and Eubacterium limosum (ATCC 8486) are presently being considered as possible COS-utilizing organisms. Both $P$. productus and $E$. limosum are anaerobic organisms capable of consuming $\mathrm{CO}$ and yroducing acetate. Acetate may also be used as the required carbon source for organisms carrying out the water gas shift reaction. $R$. rubrum is the obvious first choice since it is one of the most promising microorganisms for the water gas shift reaction studies. Other cultures may include selected $\mathrm{H}_{2} \mathrm{~S}$-reducing cultures, since $\mathrm{H}_{2} \mathrm{~S}$ is a product in the reaction between $\cos$ and water (Equation 1.2).

\subsection{Purpose}

The overall objective of this task is to develop a system of bacterial cultures that is capable of simultaneously producing $\mathrm{H}_{2}$ and removing sulfur compounds from synthesis gas. Cultures are being screened and compared for their ability to:

a. convert $\mathrm{CO}$ and water to $\mathrm{CO}_{2}$ and $\mathrm{H}_{2}$ by the water gas shift reaction $\left(\mathrm{H}_{2}\right.$ production);

b. remove $\mathrm{H}_{2} \mathrm{~S}$ from synthesis gas while producing elemental sulfur as the preferred by-product; and

c. remove COS from synthesis gas by producing $\mathrm{H}_{2} \mathrm{~S}$, elemental sulfur or other sulfur compound as a by-product. 


\subsection{EXPERIMENTAL SCREENING PROCEDURES}

All experiments have been carried out using a basal medium containing per $100 \mathrm{~mL}$ : Pfennig mineral solution, $5 \mathrm{~mL}$; Pfennig trace metal solution, $0.1 \mathrm{~mL}$; B-vitamin solution, $0.5 \mathrm{~mL}$; yeast extract (Difco), 0.05 or $0.1 \mathrm{~g}$; and $\mathrm{NaHCO}_{3}$, 0.25 or $0.4 \mathrm{~g}$ (see Table 2.1 for solution compositions). All ingredients (except for $\mathrm{NaHCO}_{3}$ ) were mixed with distilled water, heated and boiled for 2 min under anaerobic conditions. After cooling and the addition of $\mathrm{NaHCO}_{3}$, the medium was dispensed Into serum bottles ( 100 or $150 \mathrm{~mL}$ nominal volume). The bottles were capped with butyl rubber stoppers and aluminum crimp seals. Anaerobic conditions were maintained throughout the preparation by working under an atmosphere of $\mathrm{N}_{2} / \mathrm{CO}_{2}(75 \% / 25 \%)$ or $\mathrm{H}_{2} / \mathrm{CO}_{2}(75 \% / 25 \%)$. Half-filled bottles were steam-sterilized at 15 psig for 20 min.

If strict anaerobiaity was necessary, $2 \mathrm{~mL}$ of reducing agent solution $\left(2.5 \% \mathrm{Na}_{2} \mathrm{~S} \cdot 9 \mathrm{H}_{2} \mathrm{O}\right.$ or cysteine- $\mathrm{HCl} \cdot \mathrm{H}_{2} \mathrm{O}$ ) were added per $100 \mathrm{~mL}$ of medium before inoculation. In addition to above medium, this basal medium was supplemented with specific carbon substrates or growth factors as the various cultures required. A $5 \%$ inoculum was typically employed in these batch screening experiments and the $\mathrm{pH}$ was maintained close to 7.0 .

In monitoring the progress of the experiments, gas phase analyses were performed using gas chromatography, liquid phase sulfide concentrations were monitored with a sulfide probe, cell density was measured by optical density on a spectrophotometer and $\mathrm{pH}$ was measured by employing a Corning $\mathrm{pH}$ meter. Liquid and gas samples, $1.5 \mathrm{~mL}$ and $0.4 \mathrm{~mL}$, respectively, were withdrawn from the reactors during the fermentation and analyzed for cell concentration and gas phase composition. The dry cell weight concentration for Rhodospirillaceae were obtained by measuring 1 ight scatter at $540 \mathrm{~nm}$ in a 
Table 2.1

Composition of Solutions

Pfennig Mineral Solution (5)

$\mathrm{g} / \mathrm{L}$

$\mathrm{KH}_{2} \mathrm{PO}_{4}$

10.0

$\mathrm{MgCl}_{2} \cdot 6 \mathrm{H}_{2} \mathrm{O}$

$\mathrm{NaCl}$

$\mathrm{NH}_{4} \mathrm{Cl}$

6.6

8.0

$\mathrm{CaCl}_{2} \cdot 2 \mathrm{H}_{2} \mathrm{O}$

8.0

1.0

Pfennig Trace Metal Solution (5.6)

$\mathrm{g} / \mathrm{L}$

$\mathrm{ZnSO}_{4} \cdot{ }^{7} \mathrm{H}_{2} \mathrm{O}$

0.1

$\mathrm{MnCl}_{2} \cdot 4 \mathrm{H}_{2} \mathrm{O}$

0.03

$\mathrm{H}_{3} \mathrm{BO}_{3}$

$\mathrm{CoCl}_{2} \cdot 6 \mathrm{H}_{2} \mathrm{O}$

$\mathrm{CuCl}_{2} \cdot \mathrm{H}_{2} \mathrm{O}$

0.3

0.2

0.01

0.02

$\mathrm{NiCl}_{2} \cdot 6 \mathrm{H}_{2} \mathrm{O}$

0.03

$\mathrm{Na}_{2} \mathrm{MoO}_{4} \cdot 2 \mathrm{H}_{2} \mathrm{O}$

1.5

$\mathrm{Na}_{2} \mathrm{SeO}_{3}$

0.01

B-Vitamin Solution (6)

$\mathrm{mg} / \mathrm{L}$

Biotin

Folic acid

Pyridoxal $\mathrm{HCl}$

20

Lipoic acid

10

Riboflavin

60

Thiamine $\mathrm{HCl}$

50

50

Ca-D-pantothenate

50

Cyanocobalamin

50

$P$-aminobenzoic acid

50

Nicotinic acid

50 
Spectronic 21 (Milton Roy Co., Rochester, NY) and converting it to cell density using a calibration curve $\left.(\operatorname{DCW}(\mathrm{mg} / 1))=395.4 \cdot \mathrm{ABS}_{540}\right)$.

The presence of elemental sulfur crystals makes measurement of cell concentration by optical density difficult. Two methods have thus been used for measuring the cell concentration of $C$. thiosulfatophilum: direct o.d. measurement at $580 \mathrm{~nm}$ and o.d. measurement of the pigment chlorophyl at 670 $\mathrm{nm}$. For the measurement of pigment, $1 \mathrm{~mL}$ of solution was first centrifuged at 15,000 rpm for $4 \mathrm{~min}$. The supernatant water was then discarded. Methanol (1 $\mathrm{mL}$ ) was then added to dissolve the chlorophyl present in the cells, followed by centrifugation for an additional $2 \mathrm{~min}$. Methanol ( $1.5 \mathrm{~mL}$ ) was then added to the new supernatant and the absorbance measured at $670 \mathrm{~nm}$.

A calibration curve for cell concentration in $\mathrm{mg} / \mathrm{L}$ as a function of optical density at $580 \mathrm{~nm}$ is shown in Figure 2.1 and a calibration for cell concentration based upon chlorophyl content in $\mathrm{mg} / \mathrm{L}$ as a function of optical density at $670 \mathrm{~nm}$ is shown in Figure 2.2. As is noted, both calibrations yielded straight lines. These calibration curves were constructed at a late stage in the fermentation when all of the elemental sulfur had been converted to sulfate. Thus, no interference of sulfur on the direct cell concentration measurements at $580 \mathrm{~nm}$ was observed.

Gas phase $\mathrm{CO}, \mathrm{CO}_{2}$ and $\mathrm{H}_{2}$ analyses were performed on a gas chromatograph (Perkin-Elmer Sigma 300, Norwalk, CT) using an $1.8 \mathrm{~m}$ stainless steel column packed with Carbosphere, 60/80 mesh. The oven temperature was held constant at $135^{\circ} \mathrm{C}$ while the injector and thermal conductivity detector temperatures were $175^{\circ} \mathrm{C}$. Helium was used as the carrier gas at a flow rate of $40 \mathrm{~mL} / \mathrm{min}$. 


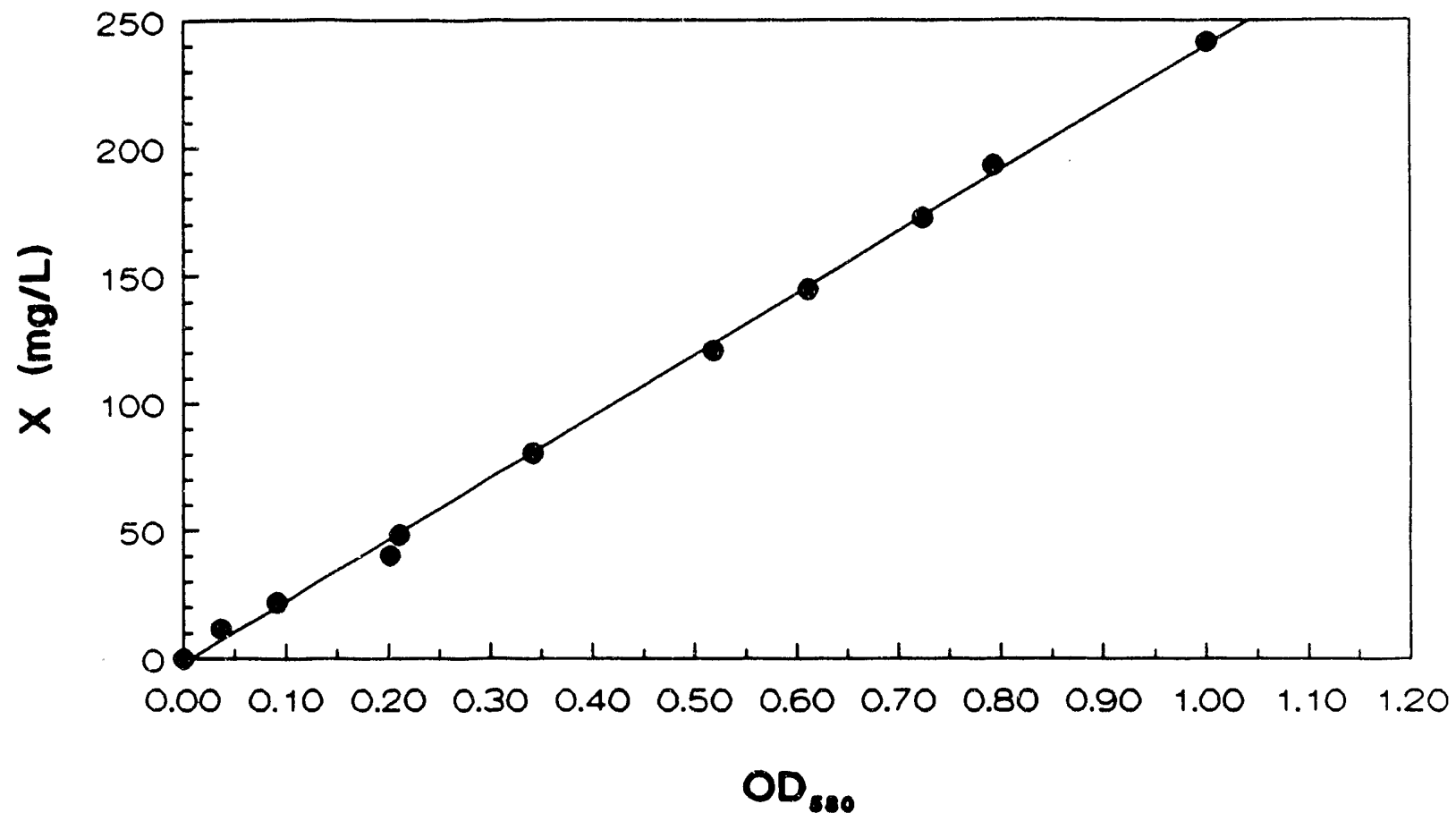

Figure 2.1 Cell Concentration Calibration Curve as a Function of Optical Density at $580 \mathrm{~nm}$ for C. thiosulfatophilum.

9 


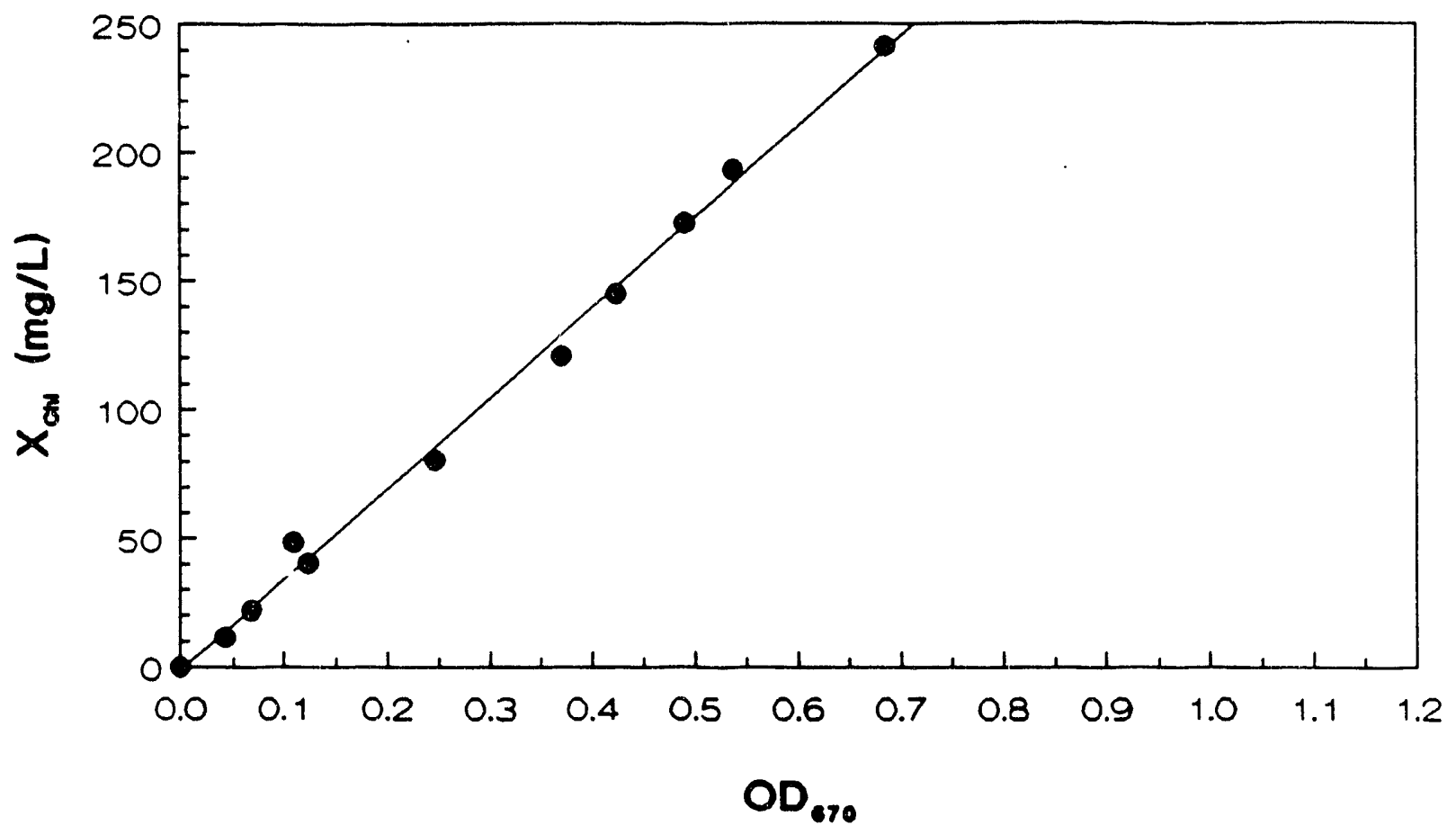

Figure 2.2 Cell Concentration Calibration Curve (Based upon Chlorophyl Content) as a Function of Optical Density at $670 \mathrm{~nm}$ for C. thiosulfatophilum. 
The gas phase $\mathrm{H}_{2} \mathrm{~S}$ and $\mathrm{COs}$ concentrations were measured by gas chromatography using a Hewlett-Packard (Kennett Square, PA) HP 5890 Series II gas chromatograph and HP 7673 integrator equipped with a thermal conductivity detector. The column was a 1/8" $\times 6^{\prime}$ teflon column packed with Chromosorb 107, 80/100 mesh (Altech Assoc., Inc., Deerfield, IL). The oven temperature was $80^{\circ} \mathrm{C}$, and the detector and injector temperatures were kept at $175^{\circ} \mathrm{C}$. the carrier gas was helium at a flow rate of $30 \mathrm{~mL} / \mathrm{min}$. Liquid phase sulfur concentrations $\left(\mathrm{H}_{2} \mathrm{~S}^{(1)}, \mathrm{HS}^{-}, \mathrm{S}^{2-}\right)$ were measured using a Corning Silver/Sulfide Electrode (Corning Glass Works, Medfield, MA) and an Orion Specific Ion meter (Orion Research, Inc., Cambridge, MA).

\subsection{RESULTS AND DISCUSSION}

\subsection{Water Gas Shift Studies}

The initial water gas shift work concentrated on growing lyophilized cells in simple basal medium with the addition of acetate and biocarbonate under a $\mathrm{H}_{2} / \mathrm{CO}_{2}$ atmosphere $(75 \% / 25 \%)$ by successive transfer. After good growth had repeatedly been obtained in this medium, small amounts of co were added to the gas phase at a partial pressure of approximately 0.16 atm. If hydrogen was produced in these initial studies, a transfer was made to identical medium and Co was again added after growth was observed.

The results of these initial experiments with the four Rhodospirillaceae are shown in Table 3.1. As is noted, all of the cultures except R. gelatinosa were identified as $\mathrm{H}_{2}$-producers under the conditions employed. All of the organisms showed good growth on acetate, with $\mathrm{H}_{2}$ production the most prominent so far in cultures reduced with cysteine-HCl. So far the most promising microorganisms are $R$. palustris, together with previously studied $R$. rubrum. $R$. rubrum has previously been shown to grow and completely convert all co 
Table 3.1

Initial Results of Water Gas Shift Reaction Studies

\begin{tabular}{|c|c|c|c|c|}
\hline Culture & Reducing Agent & Growth & H2 Production & $\begin{array}{l}\text { Microscope } \\
\text { Observation }\end{array}$ \\
\hline \multirow[t]{2}{*}{$\underline{R}$ tenuis } & $\begin{array}{l}\mathrm{Na}_{2} \mathrm{~S} \\
\text { Cysteine-HCl }\end{array}$ & $\begin{array}{l}++ \\
+\end{array}$ & $\begin{array}{l}\text { ns } \\
+\end{array}$ & $\begin{array}{l}\text { Thin rod-shaped, form } \\
\text { large dense mats and } \\
\text { clusters }\end{array}$ \\
\hline & None & + & ns & \\
\hline R. palustris & $\begin{array}{l}\mathrm{Na}_{2} \mathrm{~S} \\
\text { Cysteine-HCl } \\
\text { None }\end{array}$ & $\begin{array}{l}n \\
+++ \\
++\end{array}$ & $\begin{array}{l}\text { ns } \\
++ \\
+++\end{array}$ & $\begin{array}{l}\text { Thin crooked rod shaped, } \\
\text { form small star-like } \\
\text { clusters }\end{array}$ \\
\hline R. gelatinosa & $\begin{array}{l}\mathrm{Na}_{2} \mathrm{~S} \\
\text { Cysteine- } \mathrm{HCl} \\
\text { None }\end{array}$ & $\begin{array}{l}++ \\
+ \\
++\end{array}$ & $\begin{array}{l}\text { ns } \\
\cdots \\
\text { ns }\end{array}$ & $\begin{array}{l}\text { Thin rod shaped, non- } \\
\text { descriptive }\end{array}$ \\
\hline R. vannielii & $\begin{array}{l}\mathrm{Na}_{2} \mathrm{~S} \\
\text { Cysteine-HCl } \\
\text { None }\end{array}$ & $\begin{array}{l}+ \\
+ \\
++\end{array}$ & $\begin{array}{l}\text { ns } \\
++ \\
\text { ns }\end{array}$ & $\begin{array}{l}\text { Lemon shaped, flagellated, } \\
\text { form chains and aggregates }\end{array}$ \\
\hline
\end{tabular}

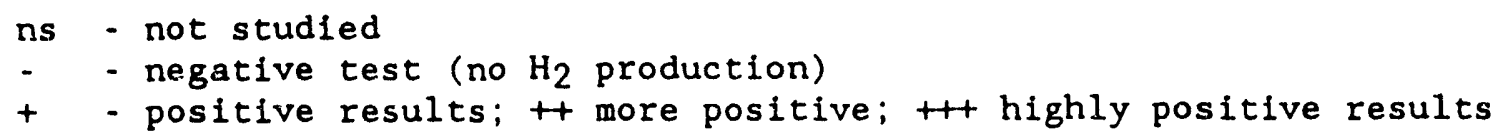


present in the gas phase to hydrogen at initial co partial pressures up to 2 $\operatorname{atm}(10)$.

Continued studies, however, where gas phase compositions and stoichiometric relationships were closely followed, showed that even though substantial amounts of $\mathrm{H}_{2}$ were produced, $\mathrm{CO}$ was not consumed. These experiments were conducted in triplicate.

Based upon documented research conducted with $R$. rubrum (11), it is likely that the observed $\mathrm{H}_{2}$ production was based on a nitrogen system which liberates $\mathrm{H}_{2}$ from organic substrates (such as acetate) under ammonia or $\mathrm{N}_{2}$ Iimitations. This theory is in agreement with the results of the present study, where $\mathrm{H}_{2}$ production was initiated after substantial growth had been observed. It is likely that cell growth was accompanied by a limitation of ammonia and with the subsequent onset of $\mathrm{H}_{2}$ production.

More recent experiments were directed toward utilizing a modified medium (see Table 3.2). In this medium, the yeast extract content was reduced and $\mathrm{NH}_{4} \mathrm{Cl}$ was added to inhibit the formation of $\mathrm{H}_{2}$ from acetate. The results from these experiments showed that no $\mathrm{H}_{2}$ production occurred in the modified medium (see Table 3.3). Good growth was observed for $R$. palustris and slight growth was observed for $R$. vaniellii and $R$. tenue. The weak growth observed with the two latter strains is possibly related to the reduction of yeast extract in the new medium.

acclimating the cultures to $\mathrm{H}_{2}$ production/CO consumption. In addition, a small effort has been focused on the apparent production of $\mathrm{H}_{2}$ from organic substrates such as acetate. Acetate may be seen as a liquid intermediate which may be produced from co by cultures such as Peptostreptococcus productus (4), according to Equation (3.1): 
Table 3.2

Modified Media Compositions

\begin{tabular}{lcc}
\hline & $\begin{array}{c}\text { Original Medium } \\
\text { per } 100 \mathrm{~mL}\end{array}$ & $\begin{array}{c}\text { Modified Medium } \\
\text { per } 100 \mathrm{~mL}\end{array}$ \\
\hline Pfennig Minerals Solution & $5 \mathrm{~mL}$ & $5 \mathrm{~mL}$ \\
Pfennig Trace Metal Solution & $0.1 \mathrm{~mL}$ & $0.1 \mathrm{~mL}$ \\
B-vitamins Solution & $0.5 \mathrm{~mL}$ & $0.5 \mathrm{~mL}$ \\
Yeast Extract & $0.1 \mathrm{~g}$ & $0.005 \mathrm{~g}$ \\
NaHCO 3 & $0.25 \mathrm{~g}$ & $0.25 \mathrm{~g}$ \\
$\mathrm{NH}_{4} \mathrm{Cl}$ &.- & $0.27 \mathrm{~g}$ \\
\hline
\end{tabular}

For solutions composition and medium preparation, see reference (2)

Table 3.3

Results of Water Gas Shift Reaction Studies Using a Modified Medium

\begin{tabular}{|c|c|c|}
\hline Culture & Growth & $\mathrm{H}_{2}$ Production \\
\hline$R$. tenuis & + & - \\
\hline R. palustris & $+t$ & $\cdots$ \\
\hline R. vaniellii & + & $\cdots$ \\
\hline
\end{tabular}




$$
4 \mathrm{CO}+4 \mathrm{H}_{2} \mathrm{O} \rightarrow 2 \mathrm{HCO}_{3}^{-}+\mathrm{CH}_{3} \mathrm{COO}^{-}+3 \mathrm{H}^{+}
$$

The produced acetate could then be converted to $\mathrm{H}_{2}$ by several members of the Rhodospirillaceae family.

\subsection{1 $\mathrm{H}_{2}$ Production from Acetate}

Several members of the Rhodospirillaceae family have been investigated for possible production of $\mathrm{H}_{2}$ from acetate. The acetate may be seen as a liquid intermediate which may be produced by e.g. P. productus. The production of $\mathrm{H}_{2}$ from a variety of organic substrates has previously been shown in the literature (13-15). The supply of nitrogen and chemical configuration were shown to strongly affect $\mathrm{H}_{2}$ production in these cases. Since it is generally considered that the enzyme nitrogenase is responsible for the release of $\mathrm{H}_{2}$ in photosynthetic bacteria (16-18), experiments were conducted with various nitrogen sources according to the following test pattern:

Cultures: Rhodospirillum rubrum (ATCC 25903)

Rhodopseudomonas palustris (ATCC 17001)

Rhodocyclus gelatinosus

(Rhodopseudomonas gelatinosa)(ATCC 17001)

Nitrogen Source: Glutamic acid, $0.106 \%(w / v)$

$\mathrm{NH}_{4} \mathrm{Cl}, 0.038 \%$

Urea, $0.021 \%$ (base nitrogen content the same)

Carbon Source: None other than $\mathrm{CO}_{2}$

Sodium acetate $0.576 \%$

Each of the above organisms were evaluated for $\mathrm{H}_{2}$ production using a certain nitrogen source with or without acetate addition. For additional medium constituents and preparation see Table 3.4 and reference (19). 
Table 3.4

Medium Composition, for $\mathrm{H}_{2}$ Production

from Acetate per $100 \mathrm{~mL}$

$\begin{array}{ll}\text { Minerals Solution } & 5 \mathrm{~mL} \\ \text { Pfennig Trace Metals Solution } & 0.1 \mathrm{~mL} \\ \text { B-vitamins Solution } & 0.5 \mathrm{~mL} \\ \text { Yeast Extract } & 0.02 \mathrm{~g} \\ \mathrm{NaHCO}_{3} & 0.25 \mathrm{~g} \\ \text { Nitrogen Source } & \text { as indicated in text } \\ \text { Sodium Acetate } & \text { as indicated in text }\end{array}$

The minerals solution contained $10.0 \mathrm{~g} / \mathrm{L} \mathrm{KH} \mathrm{PO}_{4}, 6.6 \mathrm{~g} / \mathrm{L}$ $\mathrm{MgCl}_{2} \cdot 6 \mathrm{H}_{2} \mathrm{O}, 8.0 \mathrm{~g} / \mathrm{L} \mathrm{NaCl}$, and $1.0 \mathrm{~g} / \mathrm{L} \mathrm{CaCl} 22 \mathrm{H}_{2} \mathrm{O}$. For other solutions see reference (10)

\subsubsection{Bioreactor and Operating Conditions}

Batch fermentations were carried out in $150 \mathrm{~mL}$ glass serum bottles (Wheaton Glass Co., Millville, NJ). The bottles were sealed using butyl rubber septum stoppers and aluminum crimp seals (Bellco Glass Co., Vineland, NJ). Before steril:zation, $75 \mathrm{~mL}$ of medium were added to each bottle under a $\mathrm{He} / \mathrm{CO}_{2}(75 \% / 25 \%)$ atmosphere. The bottles were autoclaved at 15 psig for 20 minutes.

Once sterile, the bottles were inoculated with $5 \mathrm{~mL}$ of seed culture. The seed cultures had been previously growing in conditions similar to the experiment before they were used. Argon ( $20 \mathrm{~mL}$ ) was then added to each bottle as an inert tracer gas with a gas-tight syringe. This procedure allowed calculation of the amounts of $\mathrm{H}_{2}$ through the fermentation.

The experiments were carried out in a modified incubator shaker (Model G25, New Brunswick Scientific Co., Edison, NJ) at $150 \mathrm{rpm}$ and $30^{\circ} \mathrm{C}$. Tungsten light, necessary for growth, was supplied in excess in the shaker. 


\subsubsection{Analytical Techniques}

Liquid and gas samples, $2.5 \mathrm{~mL}$ and $0.4 \mathrm{~mL}$, respectively, were withdrawn from the reactors during the fermentation and analyzed for cell concentration and gas phase composition. Cell growth was obtained by measuring light scatter at $540 \mathrm{~nm}$ in a Spectronic 21 (Milton Roy Co., Rochester, NY).

Gas analyses were performad on a gas chromatograph (Perkin-Elmer Sigma 300, Norwalk, CT) using an $1.8 \mathrm{~m}$ stainless steel column packed with Carbosphere, $60 / 80$ mesh. The oven tempezature was held constant at $135^{\circ} \mathrm{C}$ while the injector and thermal conductivity detector temperatures were $175^{\circ} \mathrm{C}$. Helium was used as the carrier gas at a flow rate of $40 \mathrm{~mL} / \mathrm{min}$. The acetate concentration was analyzed with a Varian (Walnut Creek, CA) model GC-3400 gas chromatograph and a model DS-604 data station. The GC was equipped with a 3 $\mathrm{mm} \times 1.8 \mathrm{~m}, 100 / 200$ mesh, Poropak QS (Alltech, Deerfield, IL) column and a flame ionization detector. The oven temperature was maintained at $190^{\circ} \mathrm{C}$, the detector and injector temperatures were both $240^{\circ} \mathrm{C}$, and the carrier gas was helium at a flow rate of $40 \mathrm{~mL} / \mathrm{min}$.

\subsubsection{Results}

The results of the acetate fermentations conducted with $R$. rubrum are displayed in Figures 3.1-3.6. As noted in the figures, the growth (OD540) increased sharply and then leveled off towards the end of the fermentation. The highest optical density reached was 1.2 in the medium supplemented with $\mathrm{NH}_{4} \mathrm{Cl}$ and sodium acetate (or acetic acid) (see figure 3.4). The only $\mathrm{H}_{2}$ production with this culture was observed in the medium supplemented with glutamic and acetic acids (Figure 3.2). The amount produced was 0.4 mmol after $200 \mathrm{hrs}$, but decreased to $0.2 \mathrm{mmol}$ after $500 \mathrm{hrs}$. Apparently the produced $\mathrm{H}_{2}$ was being consumed during the latter part of the fermentation. 


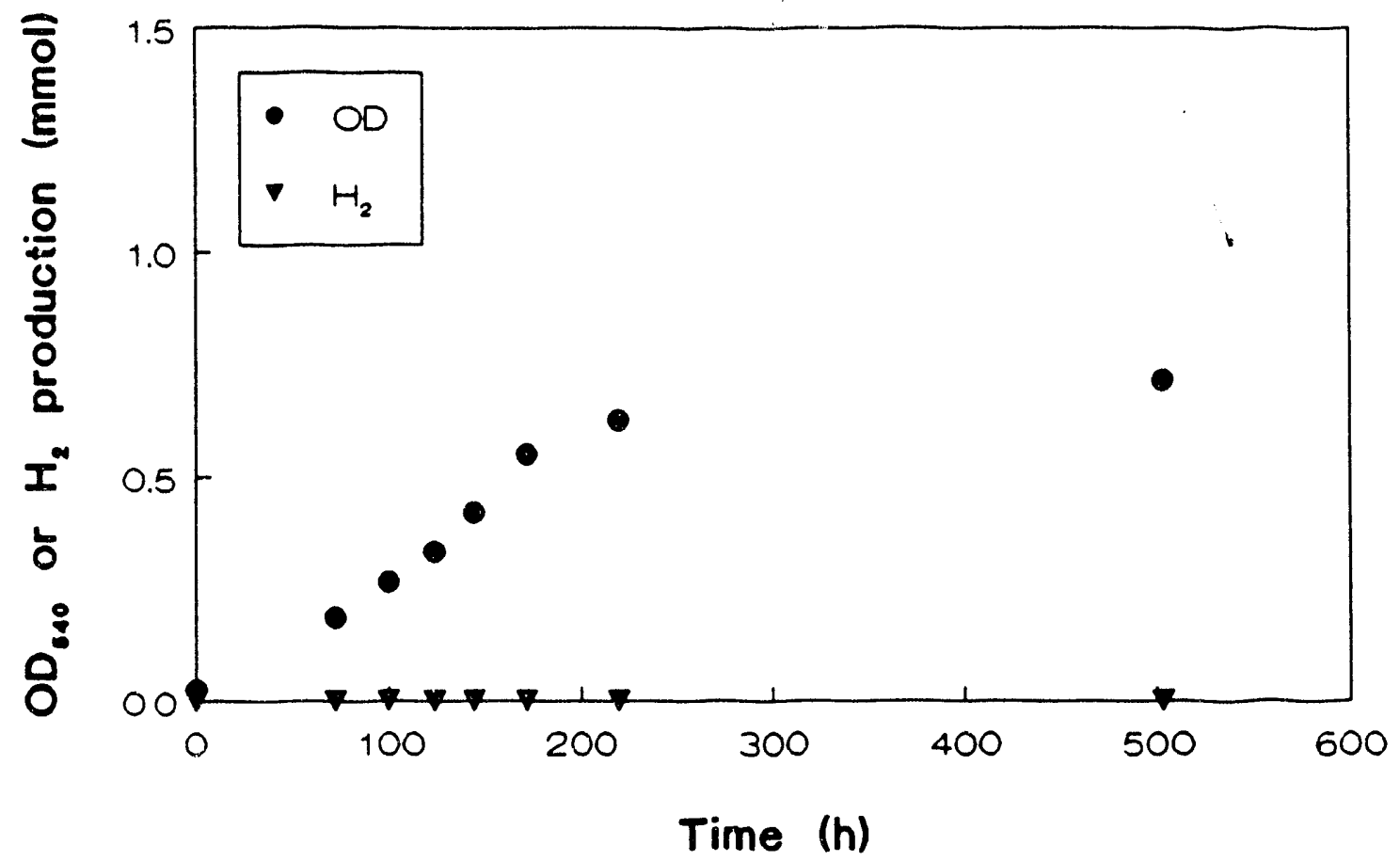

Figure 3.1 R. rubrum grown in the presence of glutamic acid.

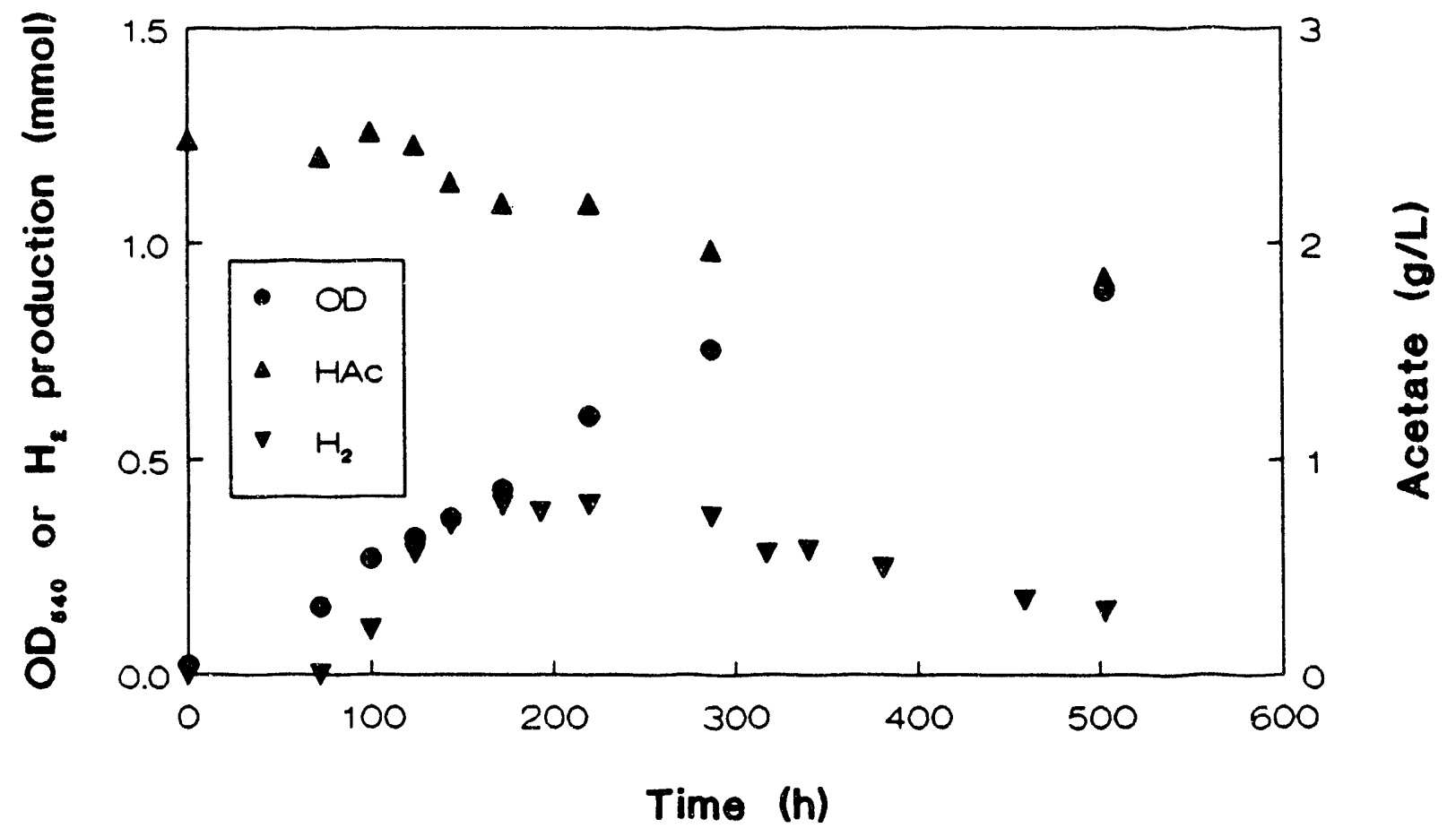

Figure $3.2 R$. rubrum grown in the presence of glutamic and acetic acids. 


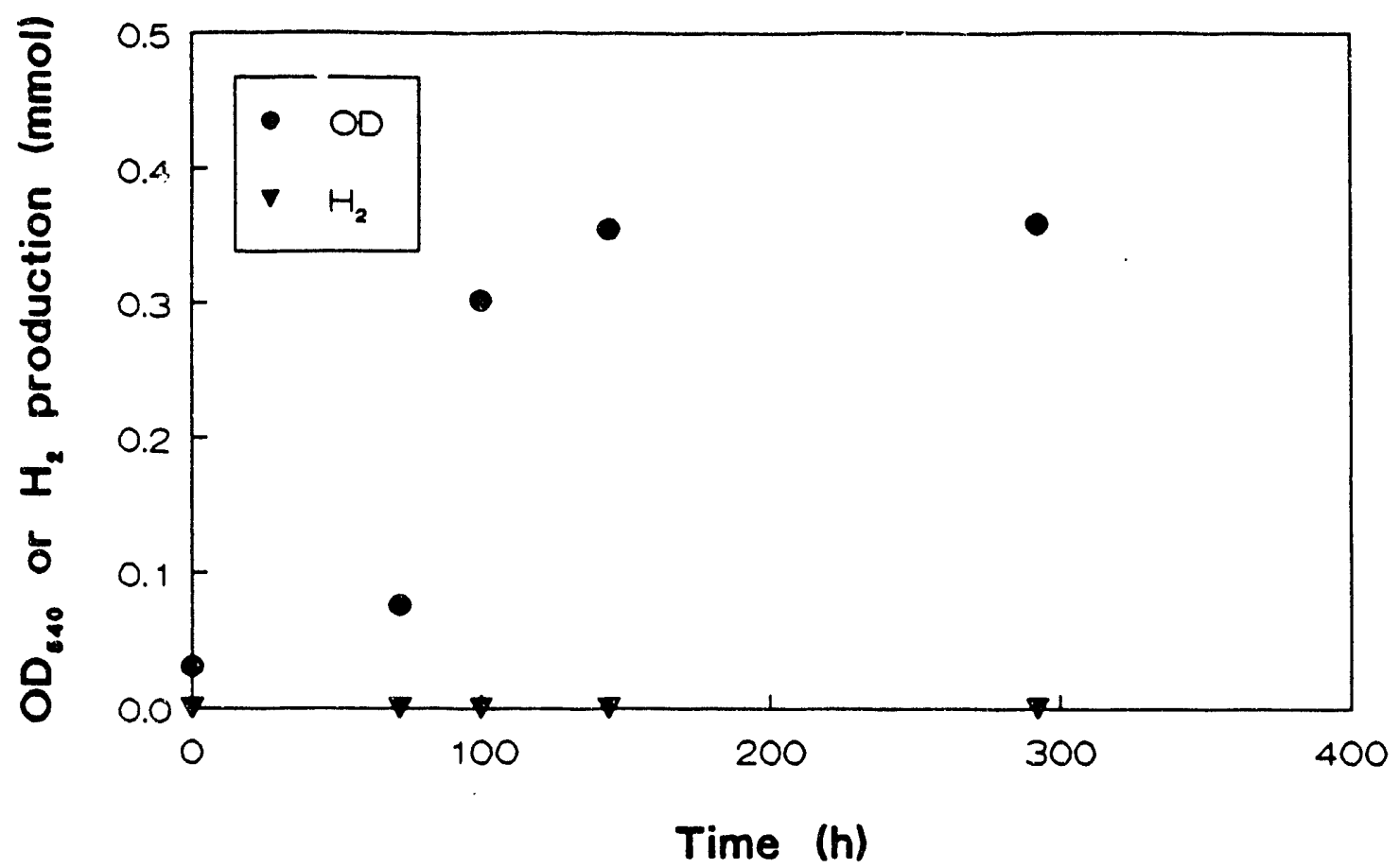

Figure $3.3 R$. rubrum grown in the presence of $\mathrm{NH}_{4} \mathrm{Cl}$.

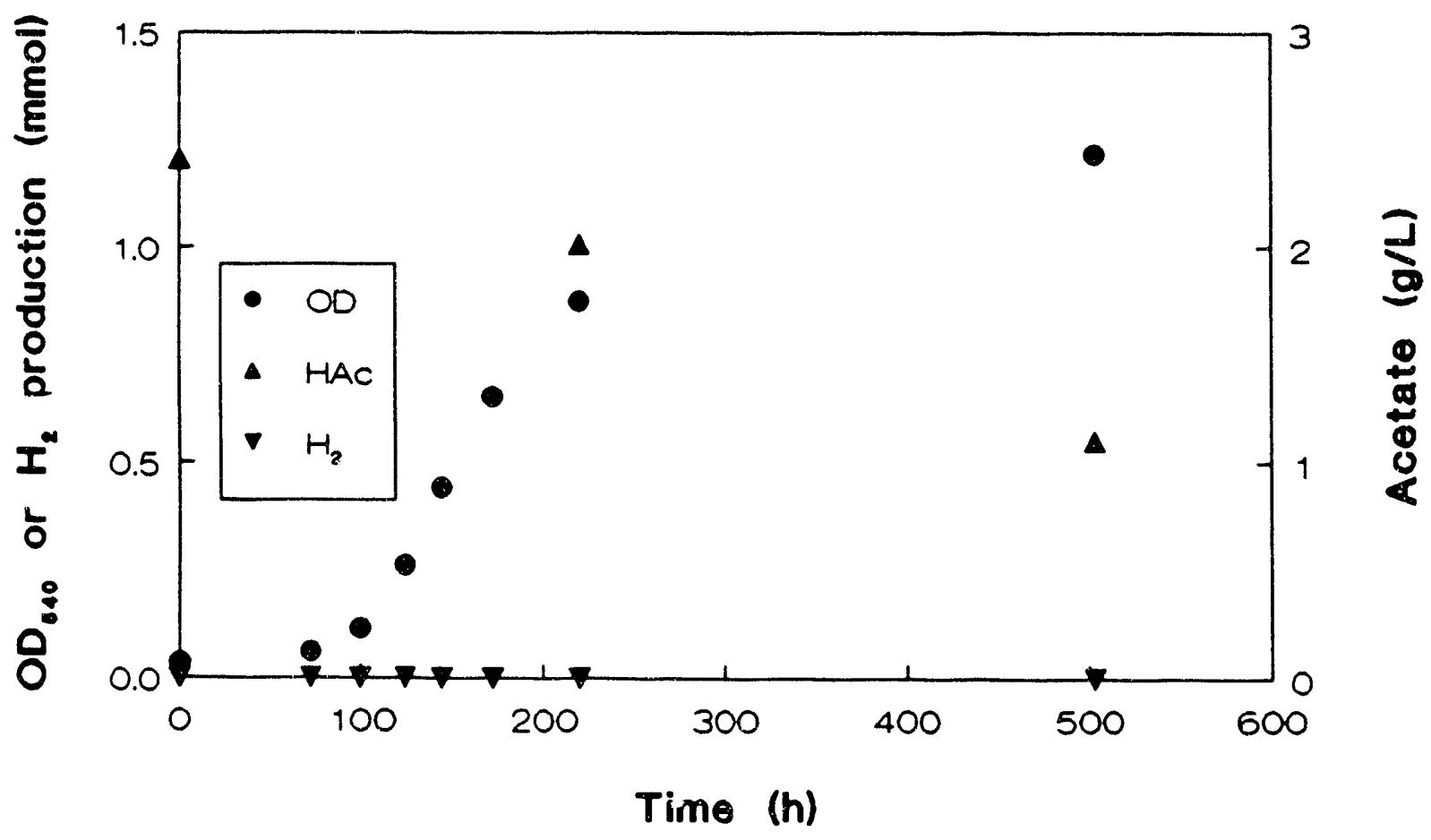

Figure $3.4 R$. rubrum grown in the presence of $\mathrm{NH}, \mathrm{Cl}$ and acetic acid. 


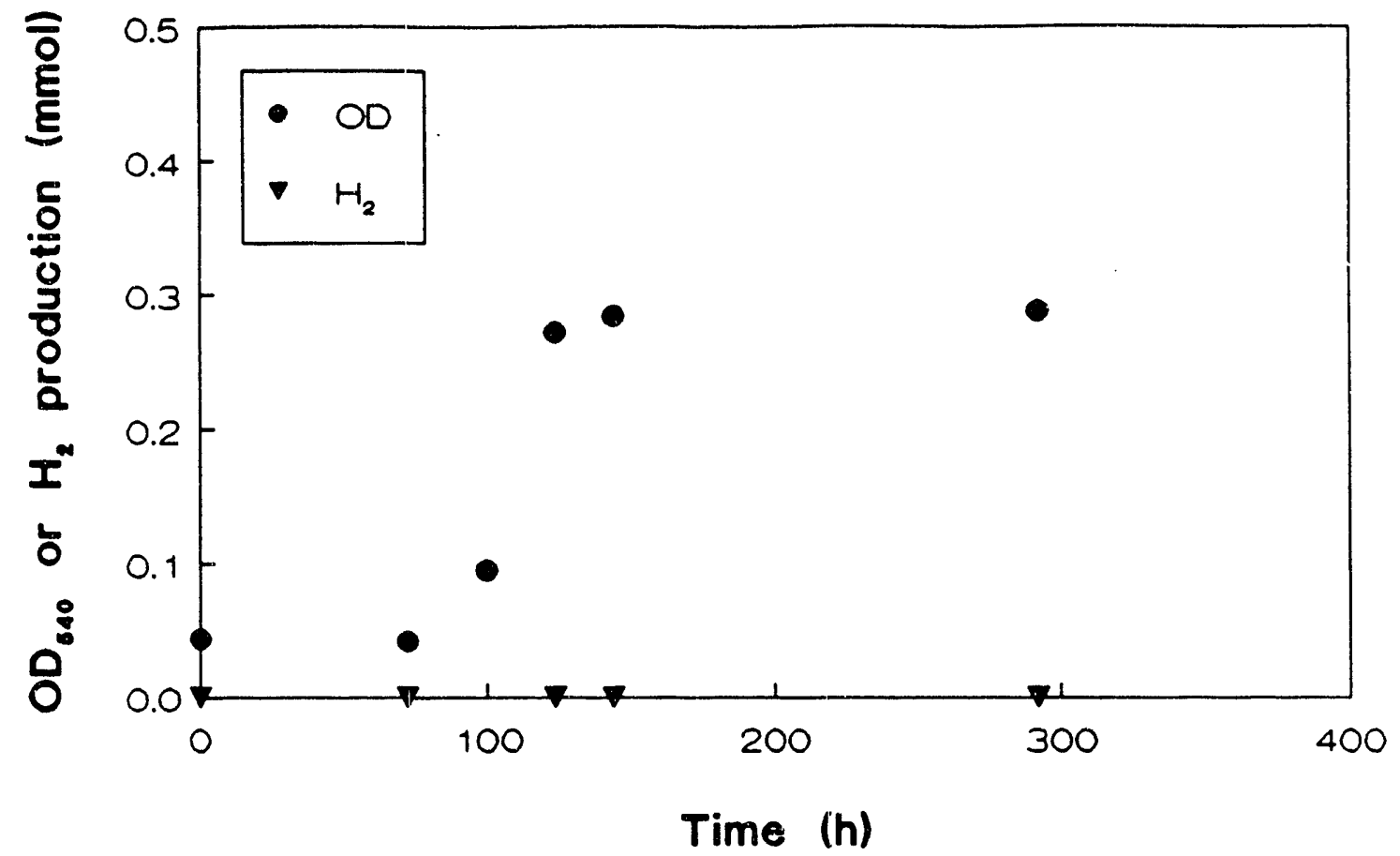

Figure $3.5 R$. rubrum grown in the presence of urea.

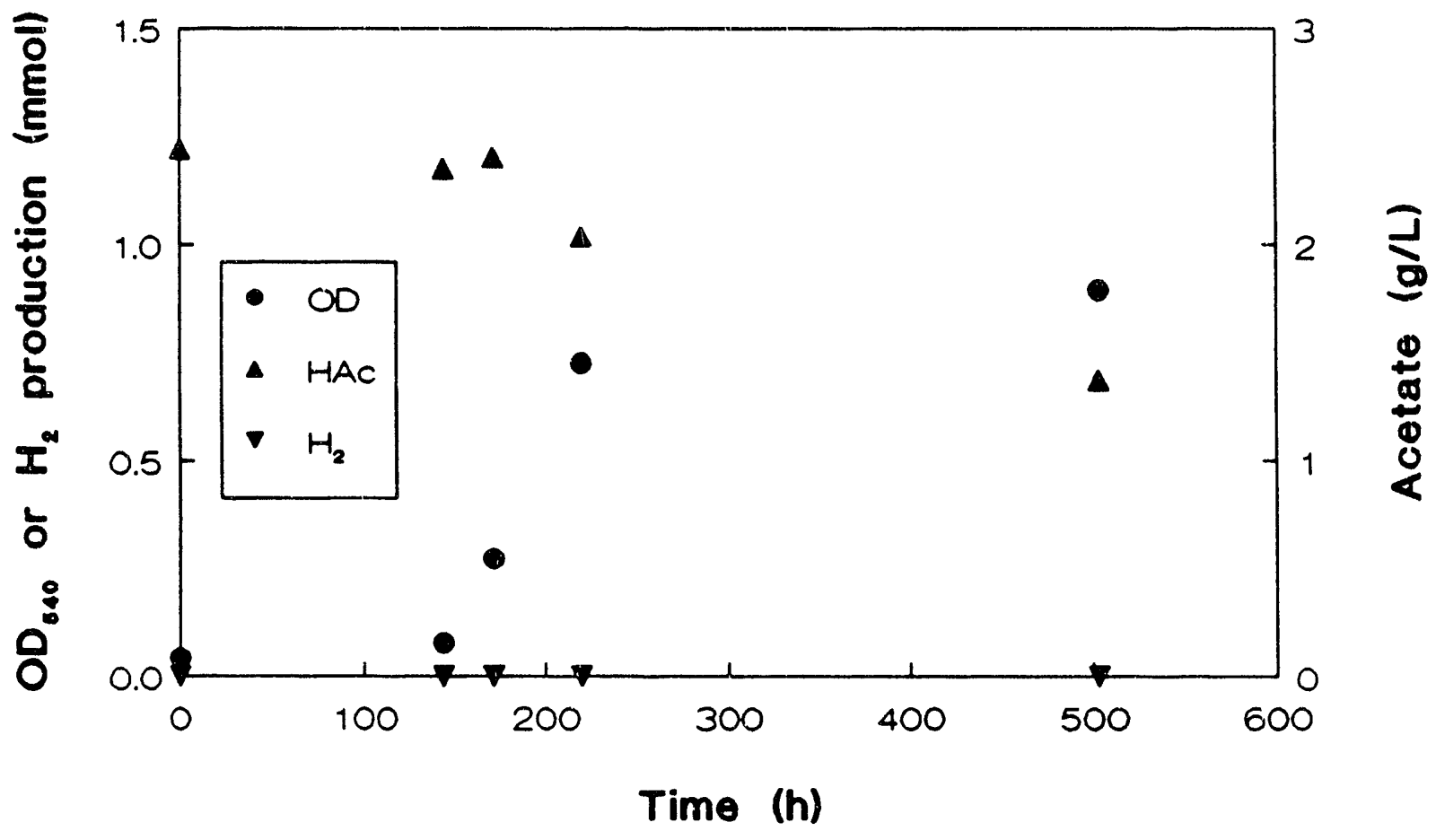

Figure $3.6 R$. rubrum grown in the presence of urea and acetic acid. 
In Figures 3.7-3.12 the results for the fermentations using $R$. palustris are displayed. In general, the medium supplemented with acetate supported the best growth. In addition, the culture in the medium with only glutamic acid grew quite well. The highest optical densities ranged from $1.2-1.4$. The production of $\mathrm{H}_{2}$ was observed in several cases (see Figures $3.7,3.8,3.10$, 3.12) with the most promising results for the experiment with glutanic and acetic acids (Figure 3.8 ). In this experiment the culture produced $1.4 \mathrm{mmol}$ of $\mathrm{H}_{2}$ in $200 \mathrm{hrs}$ and showed no signs of $\mathrm{H}_{2}$ disappearance. As is noted in Figure 3.8 , growth (OD), $\mathrm{H}_{2}$ production and acetate consumption almost ceased after 200 hrs of fermentation.

The experiments conducted with $R$. gelatinosus showed similar patterns for growth and $\mathrm{H}_{2}$ production as with the other two purple bacteria. The results are shown in Figures 3.13-3.18. As with $R$. palustris, the best growth with $R$. gelatinosus was obtained in medium supplemented with glutamic and/or acetic acids. The typical growth obtained was an OD of 1.3-1.7. The highest $\mathrm{H}_{2}$ production, $0.9 \mathrm{mmol}$, occurred in the medium with glutamic and acetic acids after 150 hrs (see Figure 3.14). This production level remained constant throughout the rest of the fermentation.

To summarize, all of the cultures produced $\mathrm{H}_{2}$ most efficiently in the medium with glutamic and acetic acids. The largest $\mathrm{H}_{2}$ production, $1.4 \mathrm{mmol}$, was observed using $R$. palustris. $\mathrm{H}_{2}$ production rates for this case are presented later in this report.

\section{$3.2 \mathrm{H}_{2} \mathrm{~S}$ Removal Studies}

The two most likely bacterial candidates capable of converting $\mathrm{H}_{2} \mathrm{~S}$ to elemental sulfur have been investigated for use in a co-culture with $R$. rubrum. These two bacteria, Chlorobium thiosulfatophilum and Chlorobium 


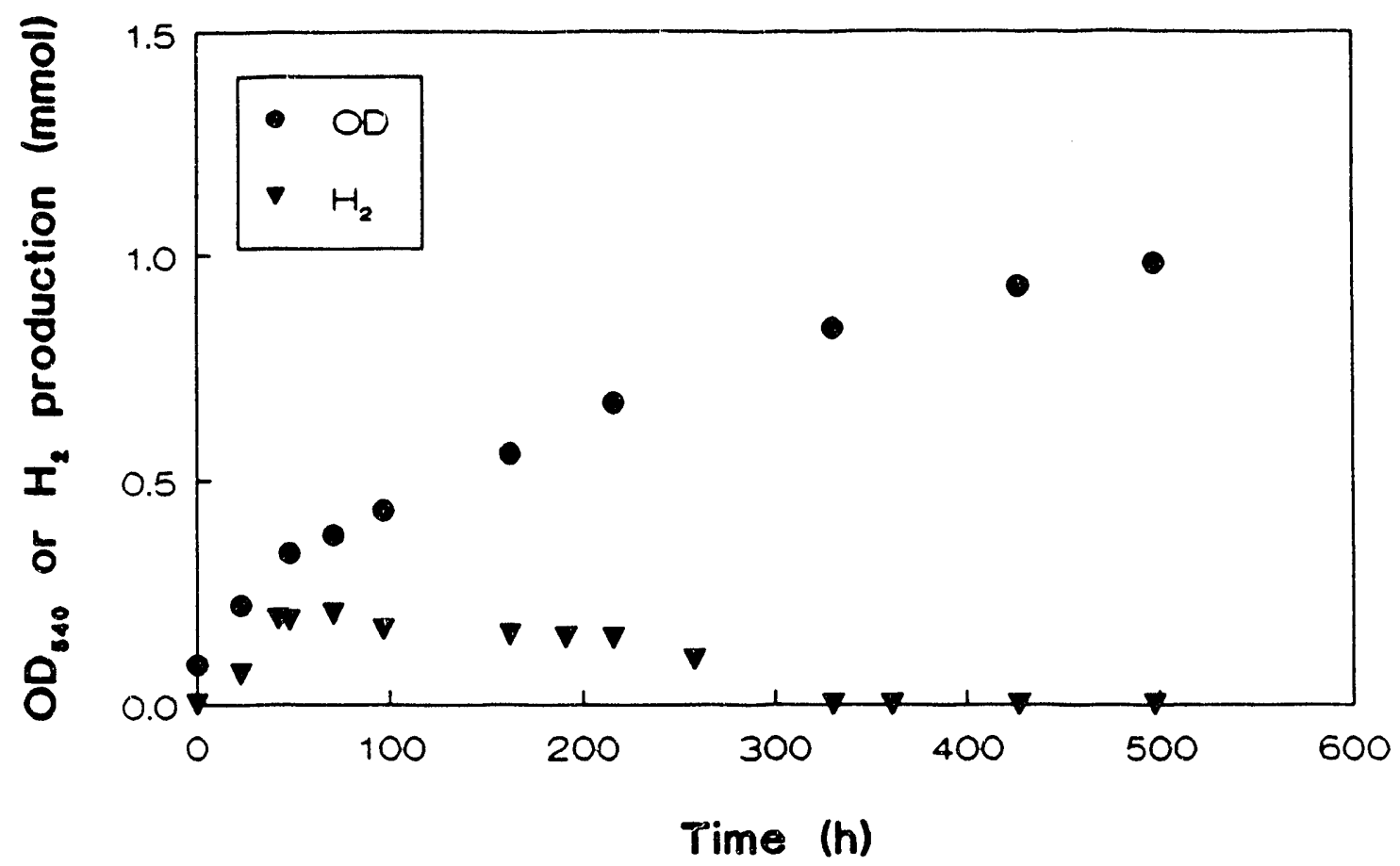

Figure $3.7 R$. palustris grown in the presence of glutamic acid.

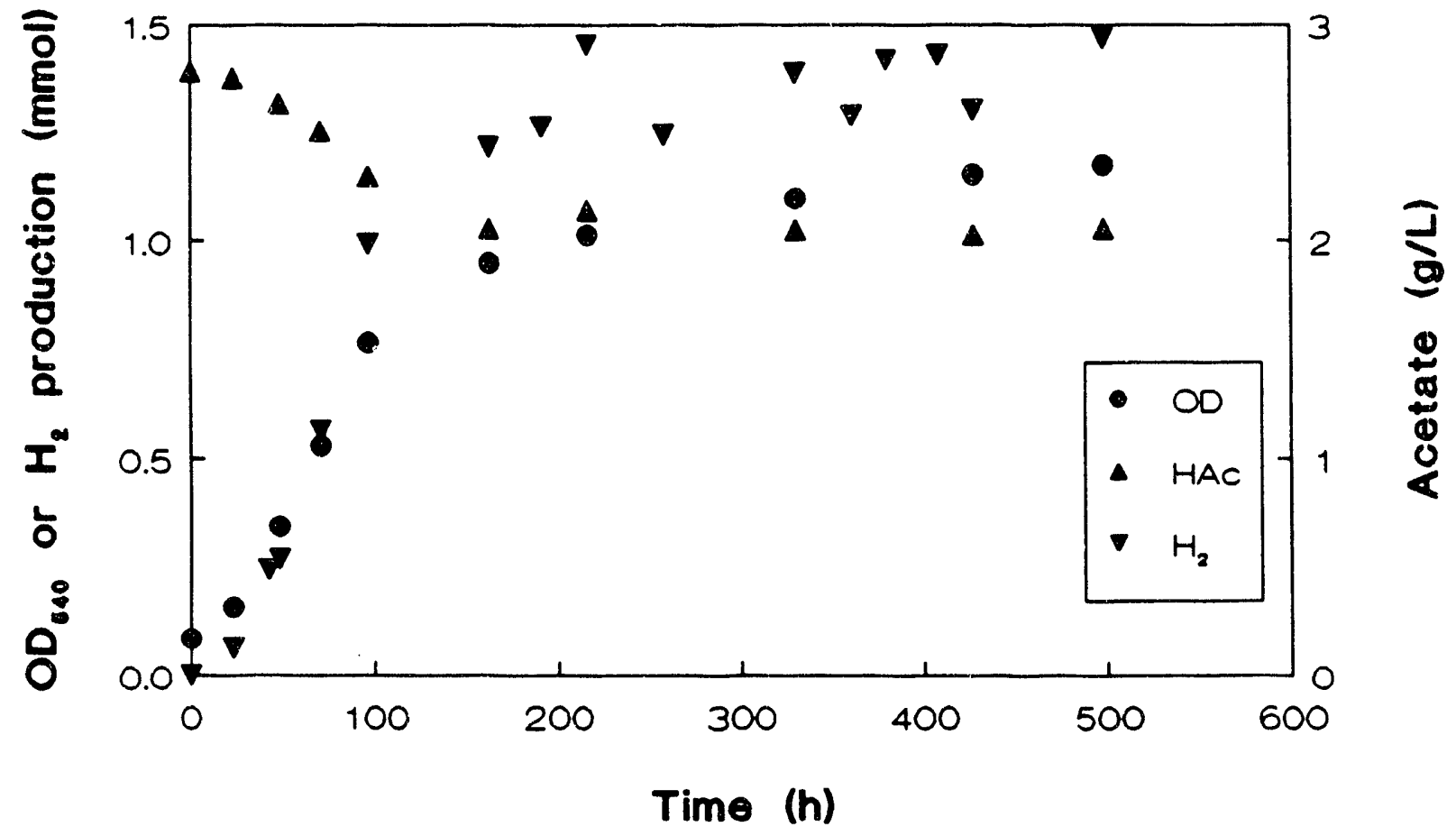

Figure $3.8 R$. palustris grown in the presence of glutamic and acetic acids. 


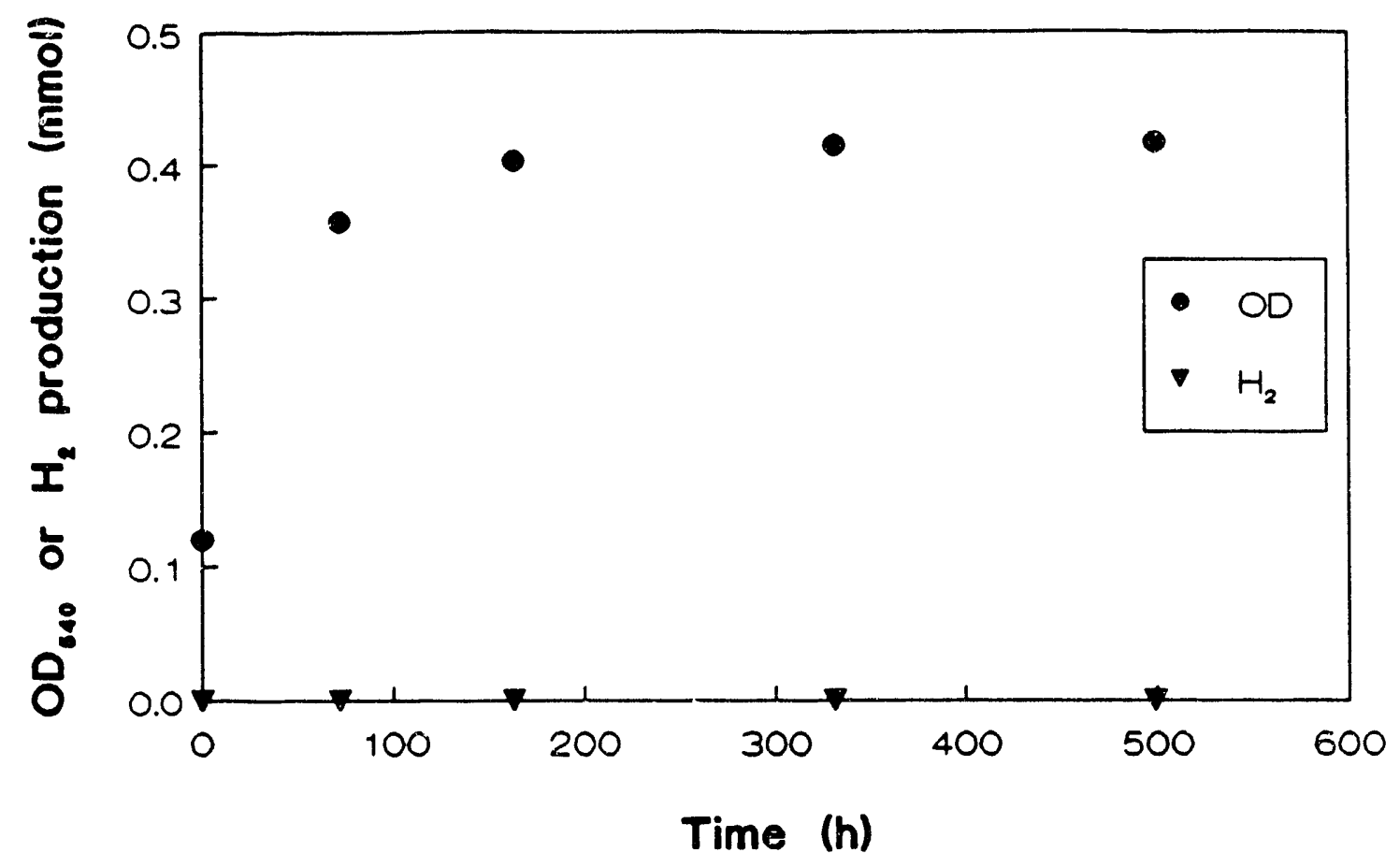

Figure $3.9 R$. palustris grown in the presence of $\mathrm{NH}_{4} \mathrm{Cl}$.

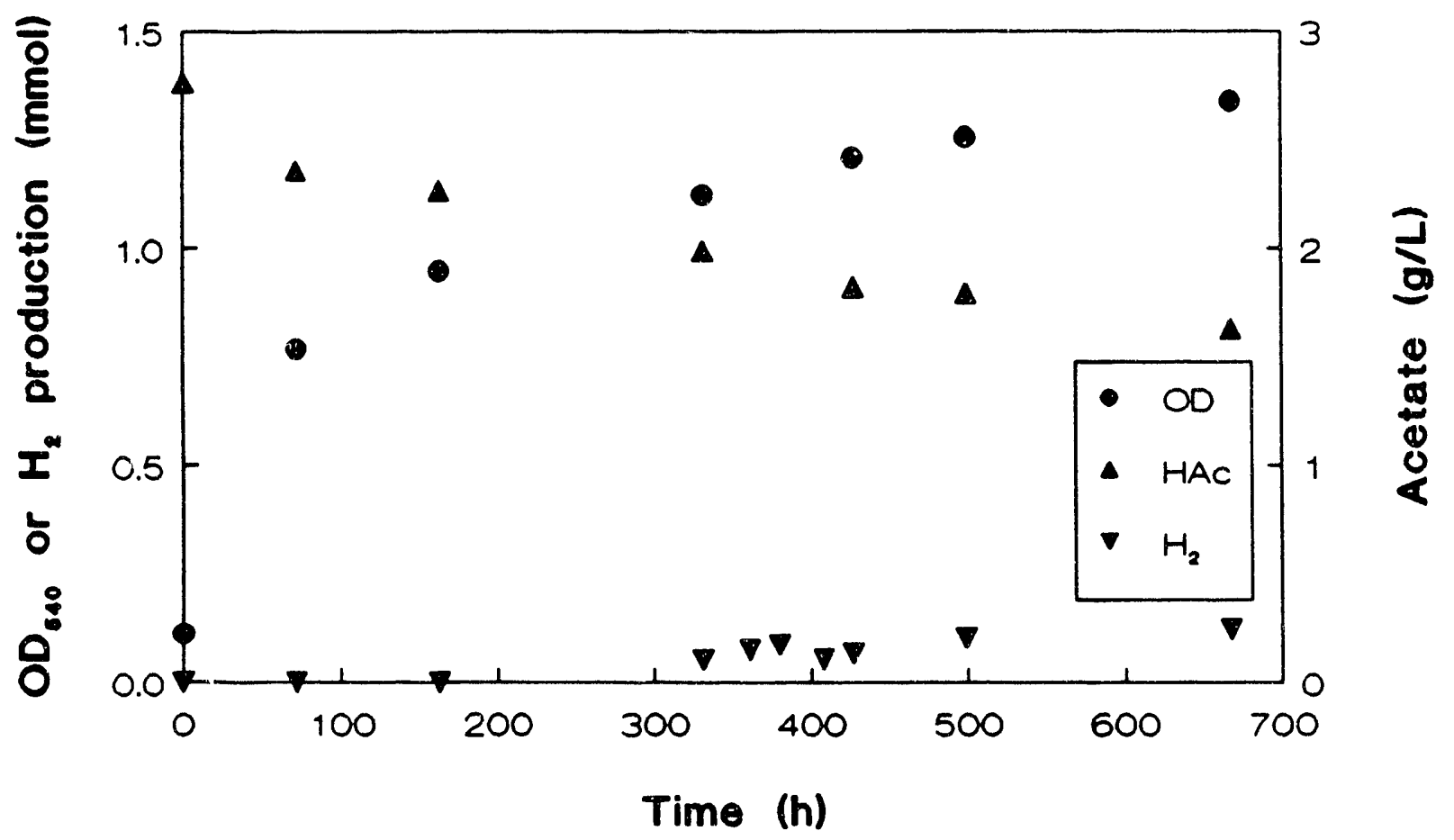

Figure $3.10 R$. palustris grown in the presence of $\mathrm{NH}_{4} \mathrm{Cl}$ and acetic acid. 


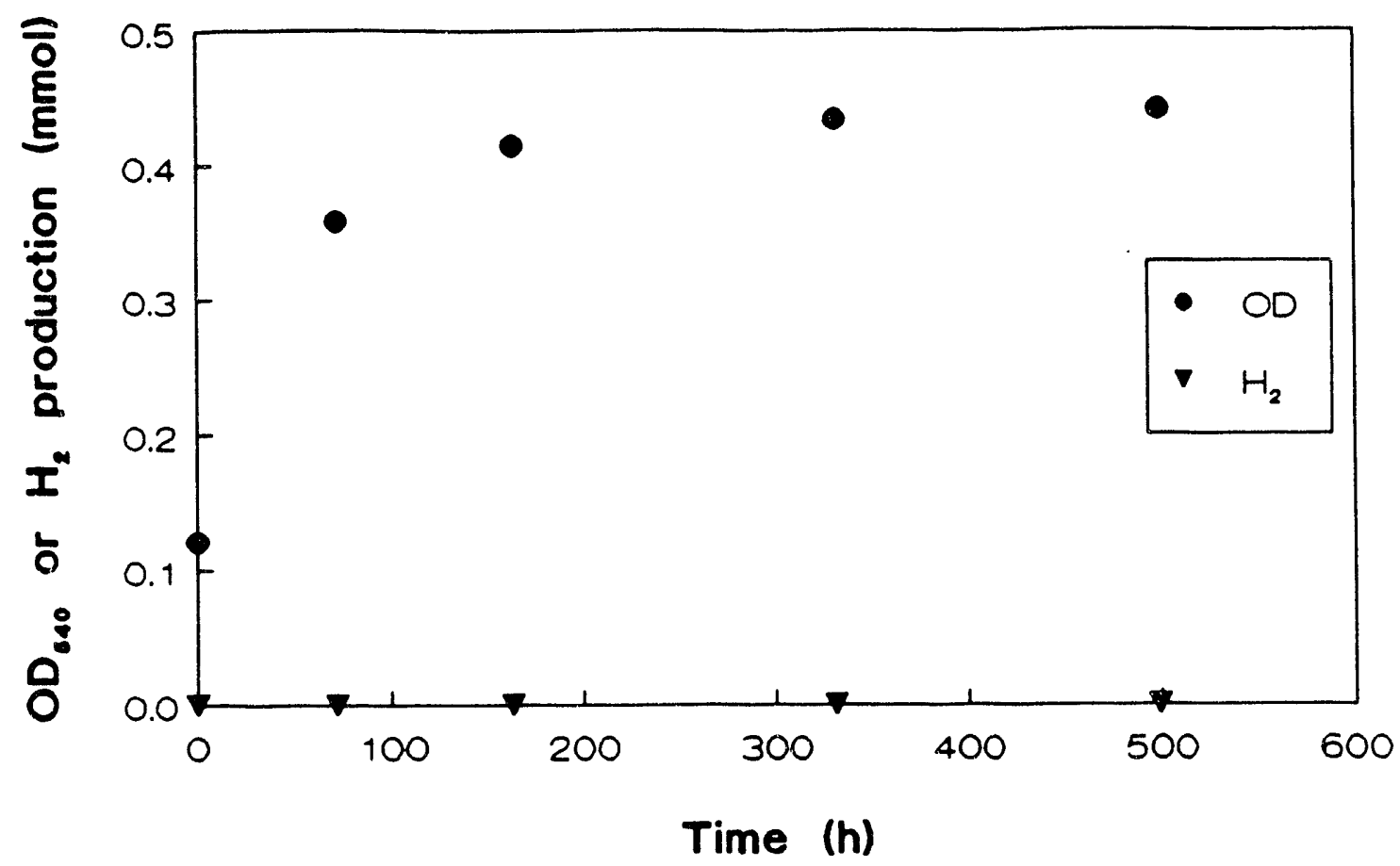

Figure $3.11 R$. palustris grown in the presence of urea.

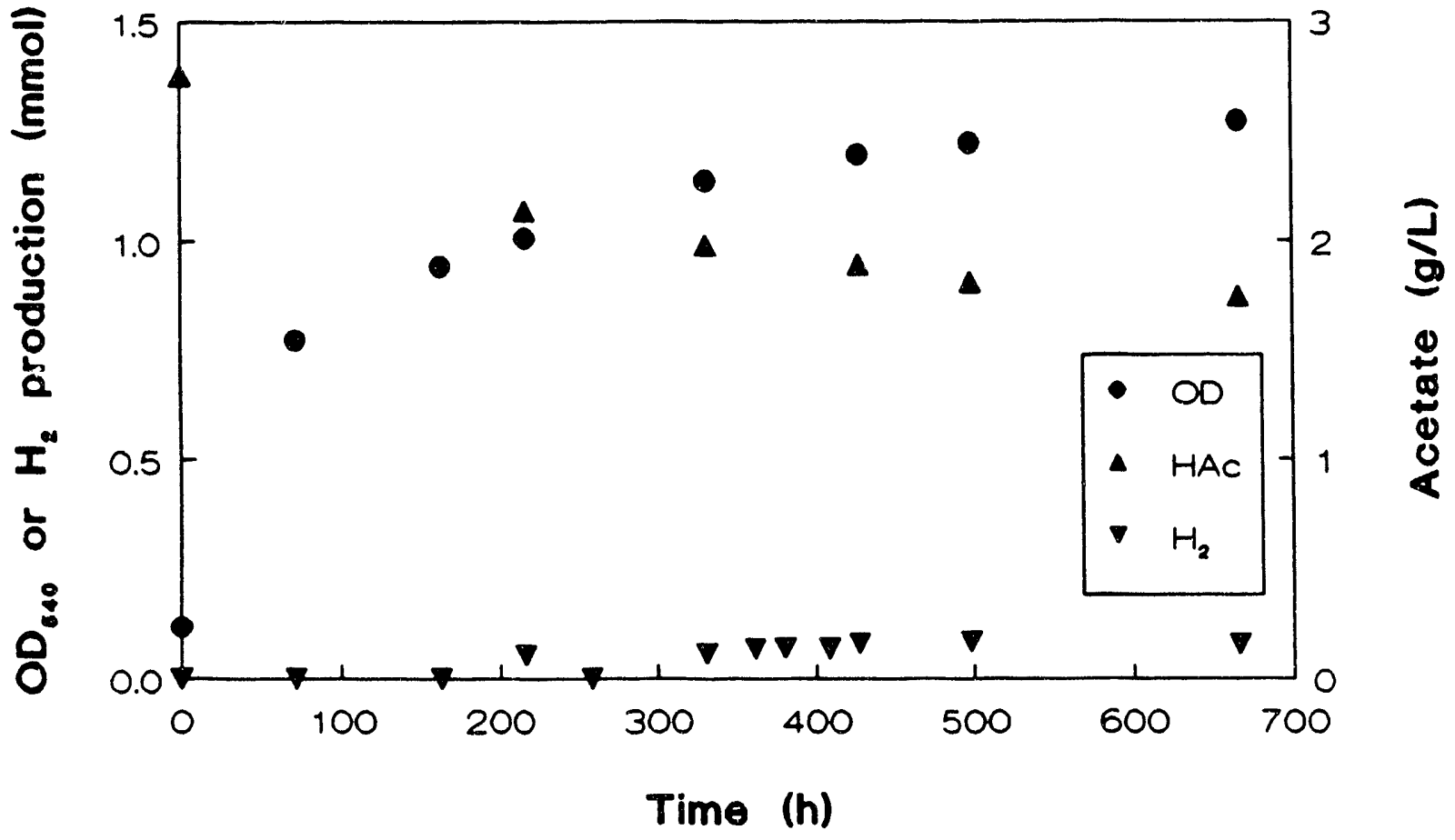

Figure $3.12 R$. palustris grown in the presence of urea and acetic acid. 


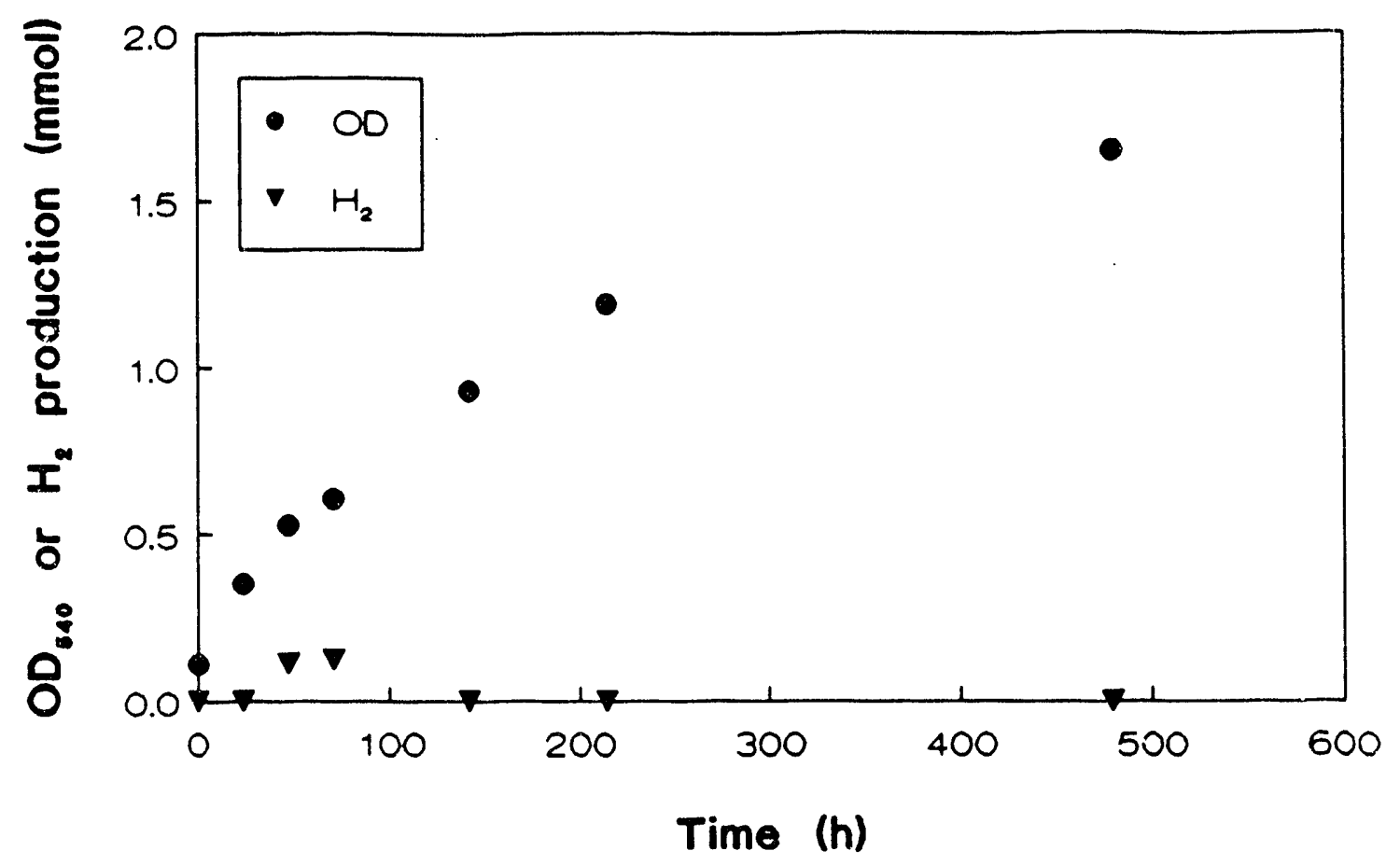

Figure $3.13 R$. gelatinosus grown in the presence of glutamic acid.

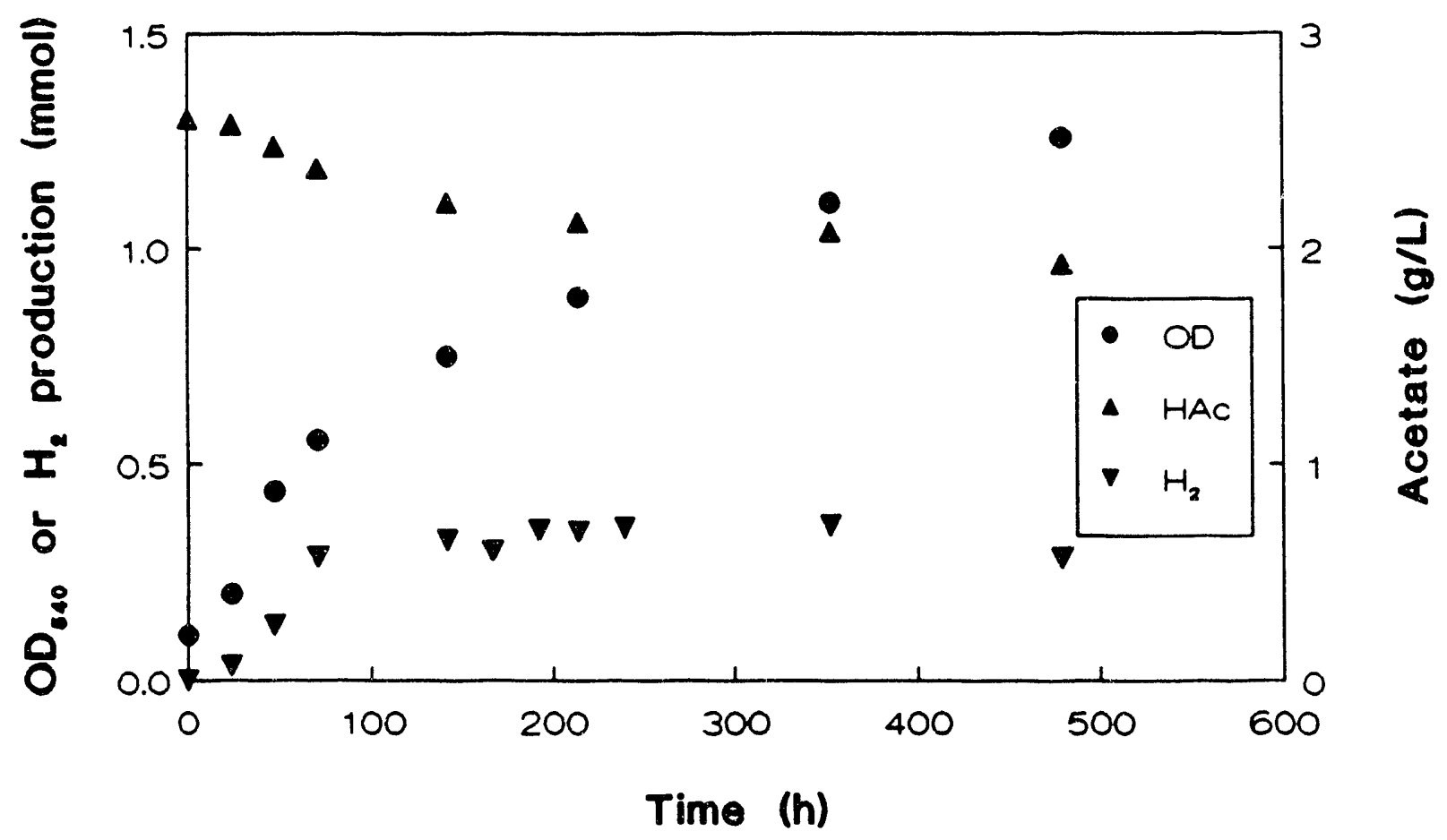

Figure $3.14 R$. gelatinosus grown in the presence of glutamic and acetic acids. 


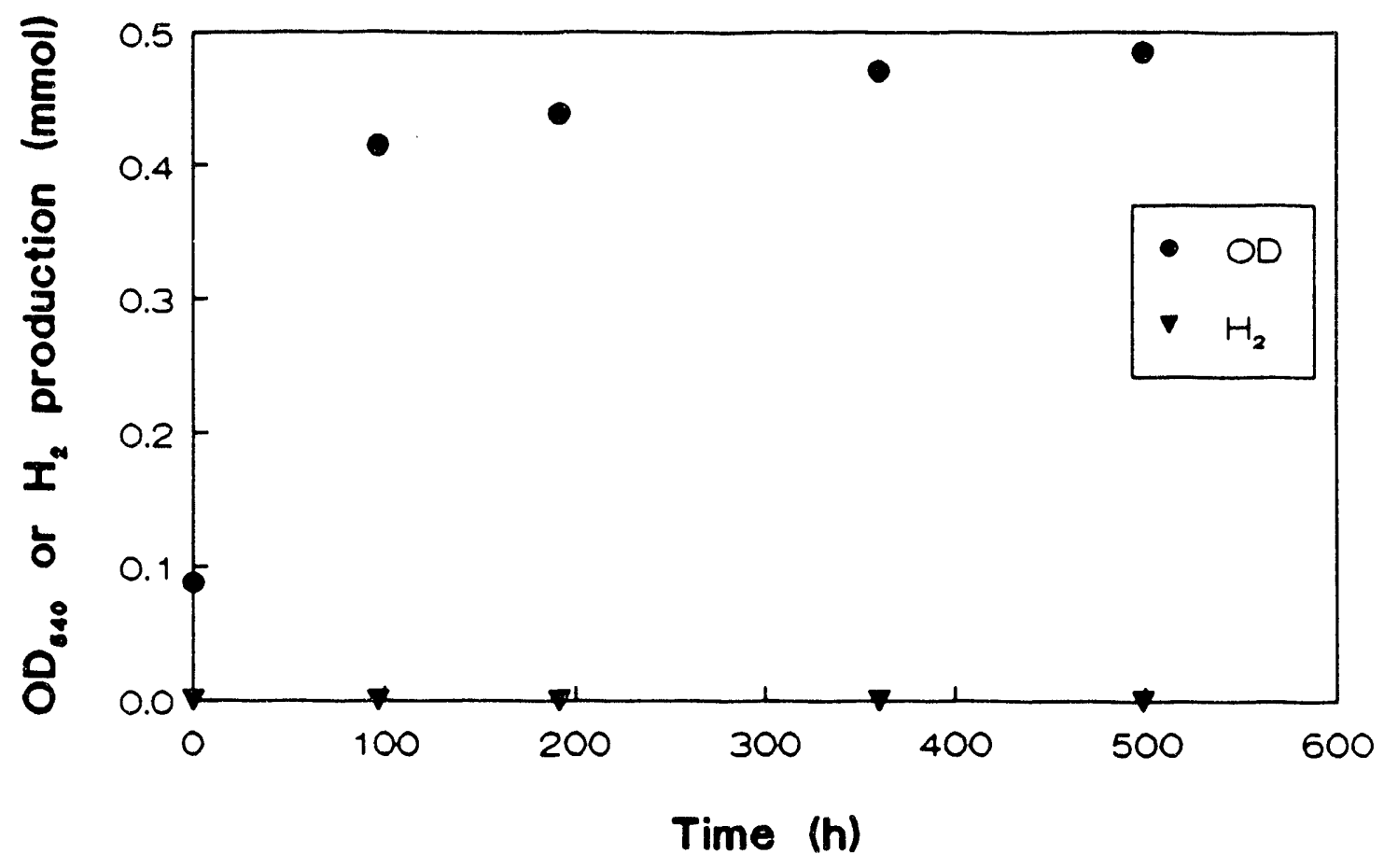

Figure $3.15 R$. gelatinosus grown in the presence of $\mathrm{NH}_{4} \mathrm{Cl}$.

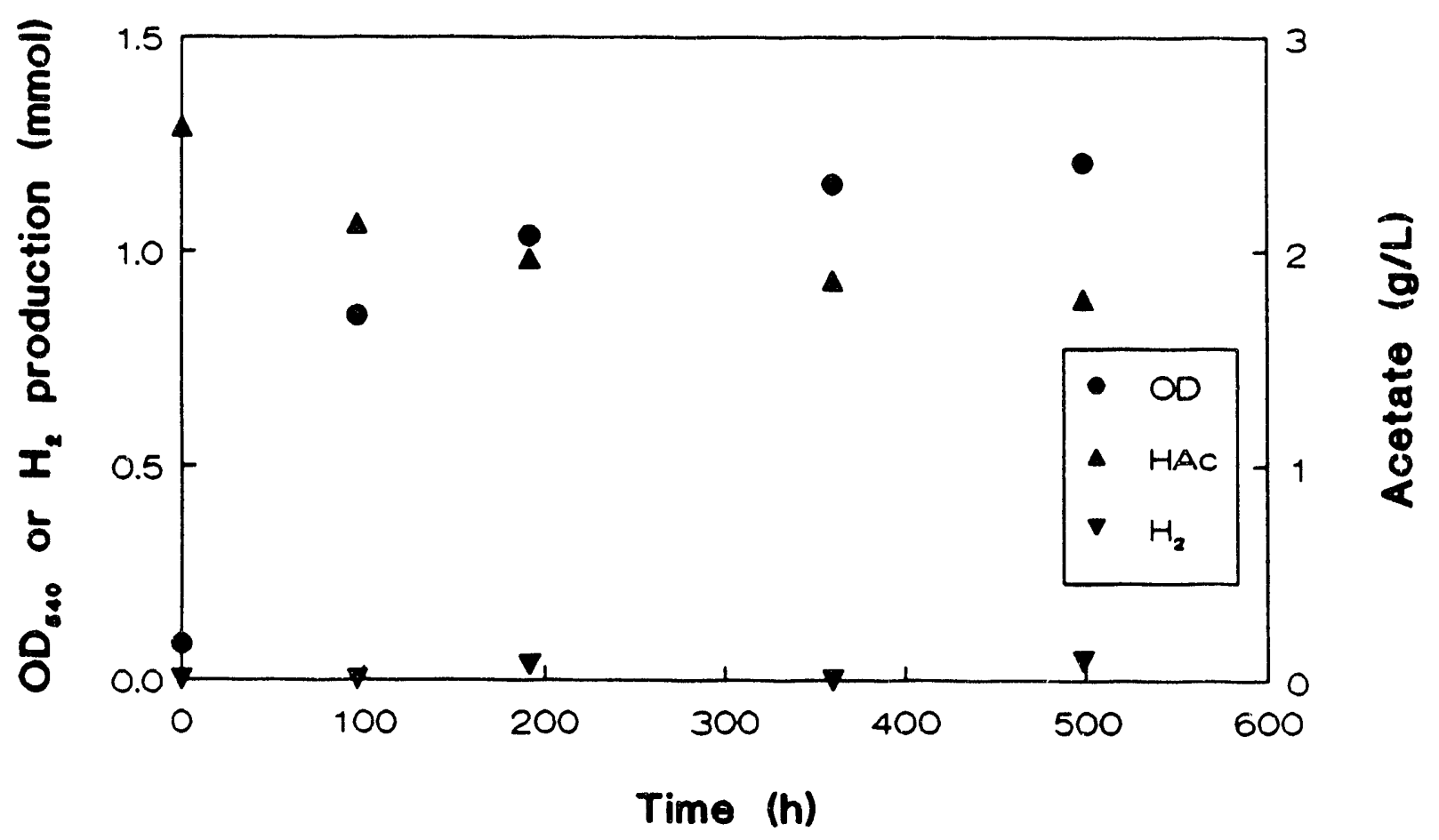

Figure 3.16 R. gelatinosus grown in the presence of $\mathrm{NH}_{4} \mathrm{Cl}$ and acetic acid. 


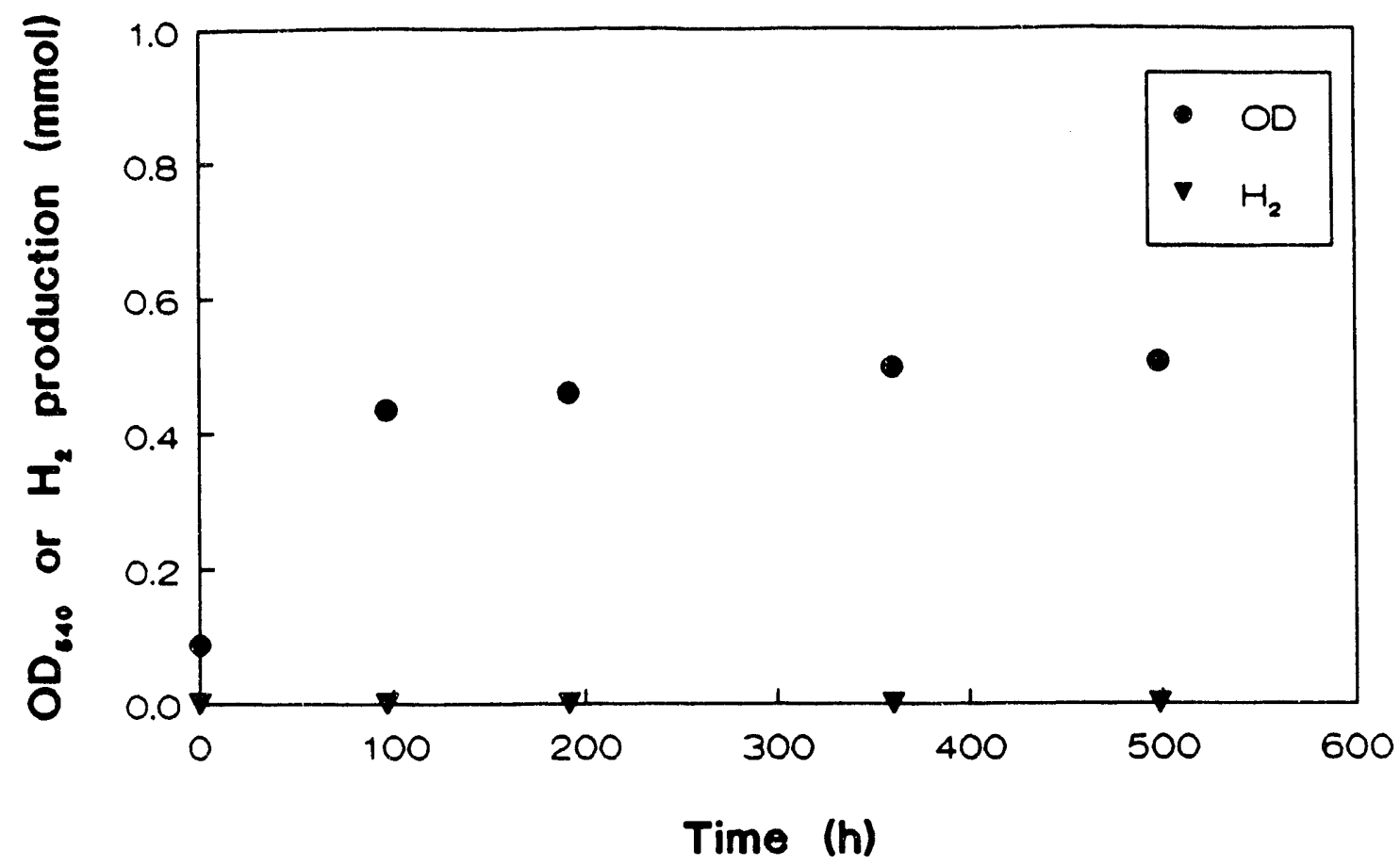

Figure $3.17 R$. gelatinosus grown in the presence of urea.

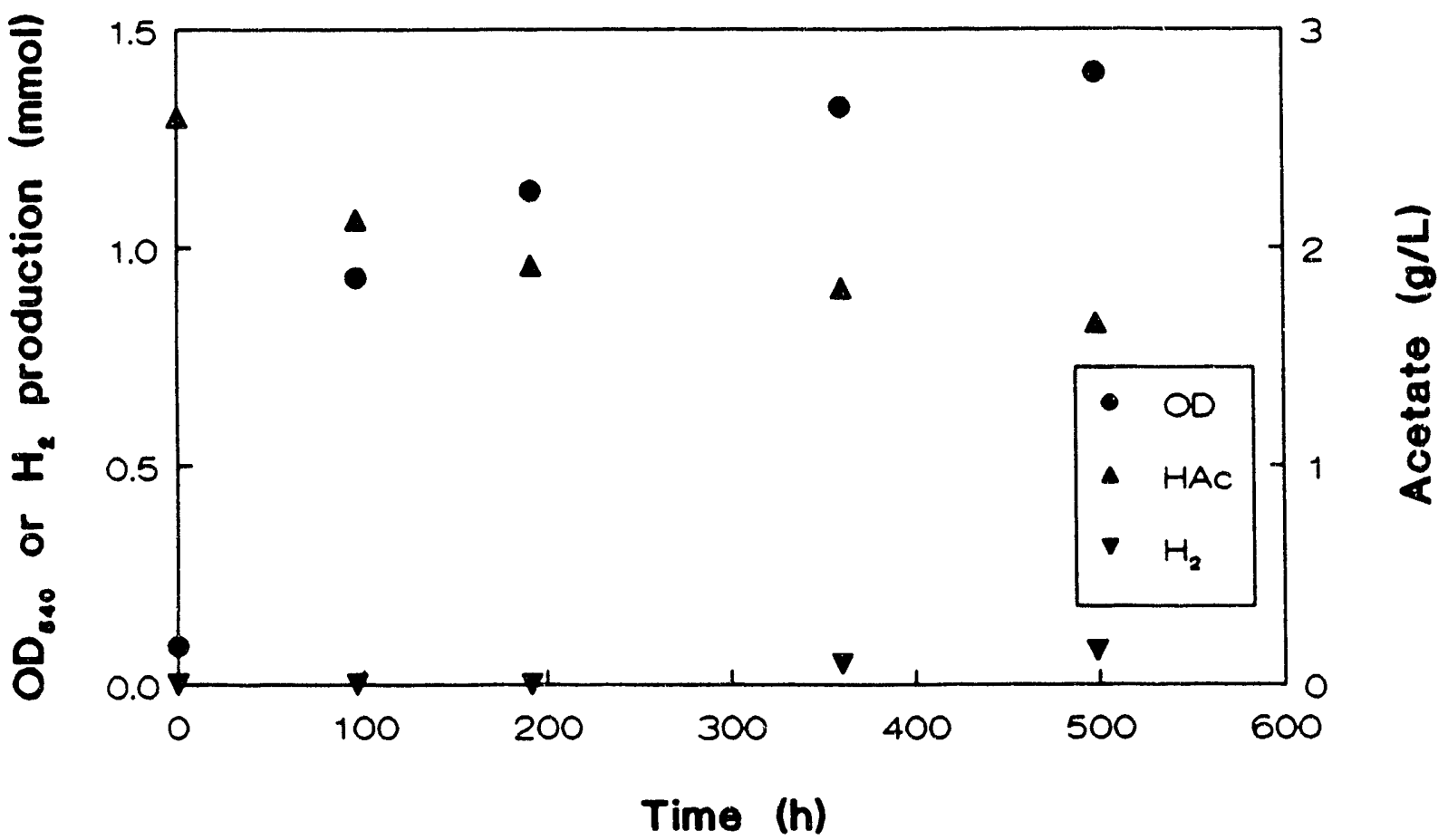

Figure $3.18 R$. gelatinosus grown in the presence of urea and acetic acids. 
phaeobacteroides, are both members of the green sulfur photosynthetic bacteria family. Both bacteria were subjected to parametric studies covering growth and $\mathrm{H}_{2} \mathrm{~S}$ uptake in order to select the best bacterium for further study.

The conditions studied and overall results of these studies are shown in Table 3.5. As is noted in the table, both bacteria are very similar in behavior for the conditions studied. Both grew well in basal medium with or without yeast extract present. Hydrogen consumption was noted for both bacteria during the latter part of the fermentation as the $\mathrm{H}_{2} \mathrm{~S}$ (added as $\mathrm{Na}_{2} \mathrm{~S}$ ) was depleted from the medium. Only $C$. thiosulfatophilum has been tested so far for the utilization of asetate (a substrate for $R$. rubrum) or acetate plus $\mathrm{NH}_{4} \mathrm{Cl}$. C. thiosulfatophilum was not inhibited by acetate and, in fact, grew on acetate as a carbon source. The bacterium also grew on basal medium supplemented with $\mathrm{NH}_{4} \mathrm{Cl}$ and acetate.

Later studies with the two bacteria have shown that $C$. phaeobacteroides often fails to grow on basal medium, while $C$. thiosulfatophilum always grows In basal medium. Also, $C$. phaeobacteroides will thus be chosen as the bacterium for $\mathrm{H}_{2} \mathrm{~S}$ conversion to elemental sulfur.

\subsection{COS Degradation}

\subsubsection{COS Degradation by Selected Co-Utilizing Bacteria}

Synthesis gas, a major product of coal gasification, typically contains 1-2 sulfur by volume, with $95.99 \%$ or more of the sulfur present as $\mathrm{H}_{2} \mathrm{~S}$ $(20,21)$. Typical levels of carbonyl sulfide (COS) in coal-derived synthesis gas range from 0.03-0.07\% by volume (22), although cos concentrations have been observed in the $5-10 \%$ range $(20,21)$. 
Table 3.5

Initial Screening of Growth Conditions of $\mathrm{H}_{2} \mathrm{~S}$ Reducers

Condition Studied

Is yeast extract

needed for growth?

Does it grow in

basal medium

Is acetate used?

Does acetate inhibit growth?

Does it use $\mathrm{H}_{2}$ as

reducing agent?

Does it grow in basal

medium supplemented with

$\mathrm{NH}_{4} \mathrm{Cl}$ and acetate?
C. thiosulfatophilum

No

Yes

Yes

No

Yes

Yes
C. phaeobacteroides

No

Yes

$-\cdot$

$\cdots$

Yes

A dash indicates that the condition has not yet been studied. 
Although $\operatorname{COS}$ is present in only small quantities, it poses serious problems to equipment and the environment. $\cos$ is corrosive to both iron and steel (23), and is a precursor to the formation of sulfur oxide derivatives, which are highly regulated environmental pollutants. $\cos$ also poses significant problems to downstream catalysts as a catalyst poison. Examples of catalysts for downstream processing of synthesis gas to methane include nickel and potassium-based catalysts, as well as mixtures of iron/chromium oxides and $z$ inc/copper oxides $(24,25)$. Poisons for these catalysts include chlorine and sulfur $(26,27)$.

It has been recently shown in the Universicy of Arkansas laboratories that some co-utilizing bacteria are capable of degrading $\cos (28)$. The results of these initial tests with various co-utilizing bacteria comparing their ability to degrade $\operatorname{COS}$ in the presence of $C O$ are shown in this report. Optimum conditions for each culture were employed as noted in the literature or determined in the laboratory. The respective rates at which cos was degraded by each culture were compared to the rate of chemical reaction of cos with water:

$$
\mathrm{COS}+\mathrm{H}_{2} \mathrm{O} \rightarrow \mathrm{H}_{2} \mathrm{~S}+\mathrm{CO}_{2}
$$

The gas phase composition was held constant in comparing the different cultures.

\subsubsection{Co-Conversion by Bacterial Cultures}

Four co-utilizing bacteria were chosen to be tested for their ability to degrade COS :

1. Peptostreptococcus productus

2. Eubacterium limosum

3. Clostridium 1jungdahlii

4. Rhodospirillum rubrum 
of the above, C. ljungdahlii, $P$. productus, and $E$. limosum convert co to acetate by the equation

$$
4 \mathrm{CO}+4 \mathrm{H}_{2} \mathrm{O} \rightarrow 2 \mathrm{HCO}_{3}-+\mathrm{CH}_{3} \mathrm{COO}-+3 \mathrm{H}^{+}
$$

$P$. productus was isolated from anaerobic sewage-digester sludge and has been reported to have a doubling time of $1.5 \mathrm{~h}$ at $37^{\circ} \mathrm{C}$ and $\mathrm{pH} 7$ (12). E. Iimosum exhibited a doubling time of $7 \mathrm{~h}$ under the same conditions (29). P. productus has been shown to be able to tolerate $\mathrm{H}_{2} \mathrm{~S}$ and $\mathrm{COS}$ concentrations as high as $20 \%$ by volume $(30)$.

C. Ijungdahlii was isolated from chicken waste at the University of Arkansas ( 31 ) and, in addition to Reaction 2, carries out the following reaction (32):

$$
6 \mathrm{CO}+7 \mathrm{H}_{2} \mathrm{O} \rightarrow \mathrm{C}_{2} \mathrm{H}_{5} \mathrm{OH}+4 \mathrm{HCO}_{3}^{-}+4 \mathrm{H}^{+}
$$

The CO conversion to ethanol is favored at low $\mathrm{pH}$ and under nutrient limitation.

$R$. rubrum, as mentioned previously, is a photosynthetic bacterium that is capable of converting $\mathrm{CO}$ and $\mathrm{H}_{2} \mathrm{O}$ to $\mathrm{HCO}_{3}{ }^{-}, \mathrm{H}^{+}$, and $\mathrm{H}_{2}$ by the following reaction (33):

$$
\mathrm{CO}+2 \mathrm{H}_{2} \mathrm{O} \rightarrow \mathrm{HCO}_{3}^{-}+\mathrm{H}_{2}+\mathrm{H}^{+}
$$

$R$. rubrum does not utilize $C O$ for growth, but is able to utilize a wide varlety of carbon sources, including acetate, malate, and yeast extract. Tungsten light is required for growth, but is not required in $C 0$ utilization (34). R. rubrum was shown to be inhibited by $\cos$ concentrations above $6 \%$ (30).

\subsubsection{Materials and Methods}

Peptostreptococcus productus, Strain U-1, was supplied by M. P. Bryant, University of Illinois, Department of Dairy Science. Eubacterium limosum, 
Strain 8486, and Rhodospirillum rubrum, Strain 25903, were obtained from the American Type Culture Collection, Rockville, MD. Clostridium ljungdahlii, Strain PETC, was isolated from chicken waste in the University of Arkansas laboratories.

The medium for the bacteria was the same as the original medium of Table 3.2 with the addition of $0.1 \mathrm{~mL}$ of $0.1 \%$ resazurin. The medium $\mathrm{pH}$ was 7.0 for $P$. productus, E. limosum, and $R$. rubrum, and 5.0 for $C$. 1 jungahlii. The experimental techniques employed in these batch comparison studies were as described previously $(19,28)$.

\subsubsection{Results and Discussion}

The experiments were designed so that $C O$ and $C O S$ served as cosubstrates for the organisms. The utilization of $C O$ in the presence of $c O S$ by the four bacteria is shown in Figures 3.19-3.22. The disappearance of $\mathrm{CO}$ in the medium alone is also shown for comparison purposes. As is noted in the figures, the rate of CO consumption increased with inoculum size. Furthermore, all organisms yielded essentially complete conversion for all inoculum sizes in 25 $h$ or less. CO was not degraded in the medium alone.

The uptake of $\operatorname{COS}$ in the presence of $\mathrm{CO}$ by the bacteria is shown in Figures 3.23-3.26. P. productus, E. limosum, and $R$. rubrum showed an ablilty to degrade $\cos$ faster than the reaction of $\operatorname{COS}$ with water in the medium. $C$. ljungdahlii, on the other hand, was not shown to utilize or degrade cos any faster than medium alone. it should be pointed out that the cos profiles with medium alone were run at identical $\mathrm{pH}$ levels and temperatures as the CO-COS degradation experiments. Thus, for experiments with $P$. productus and $E$. limosum, a medium at $\mathrm{pH} 7$ and $37^{\circ} \mathrm{C}$ was used, and for experiments with $C$. ljungdahlii a medium at $\mathrm{pH} 5$ and $37^{\circ} \mathrm{C}$ was used. A medium at $\mathrm{pH} 7$ and $30^{\circ} \mathrm{C}$ was 


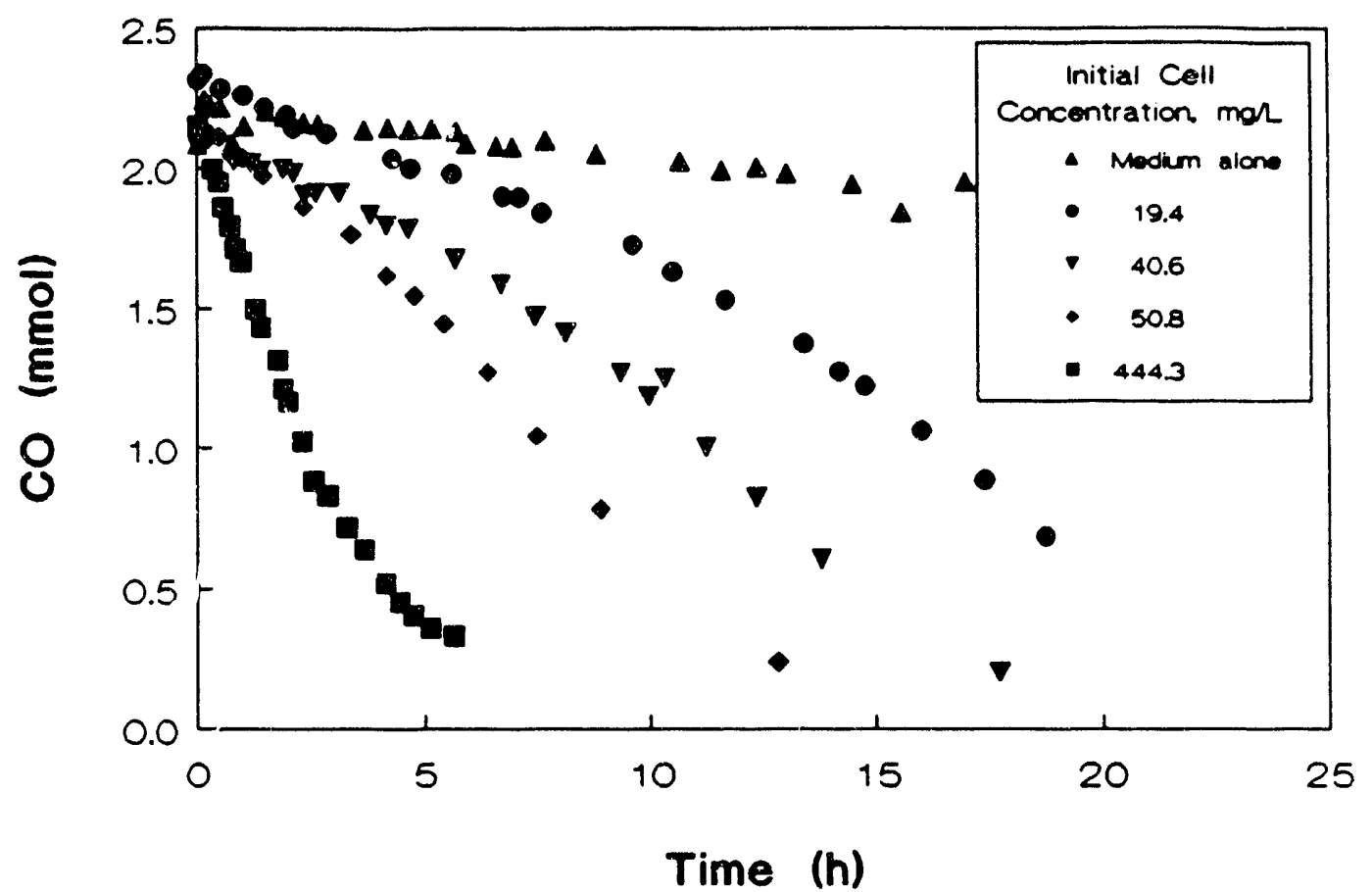

Figure 3.19 CO uptake by $P$. productus in the presence of COS. 


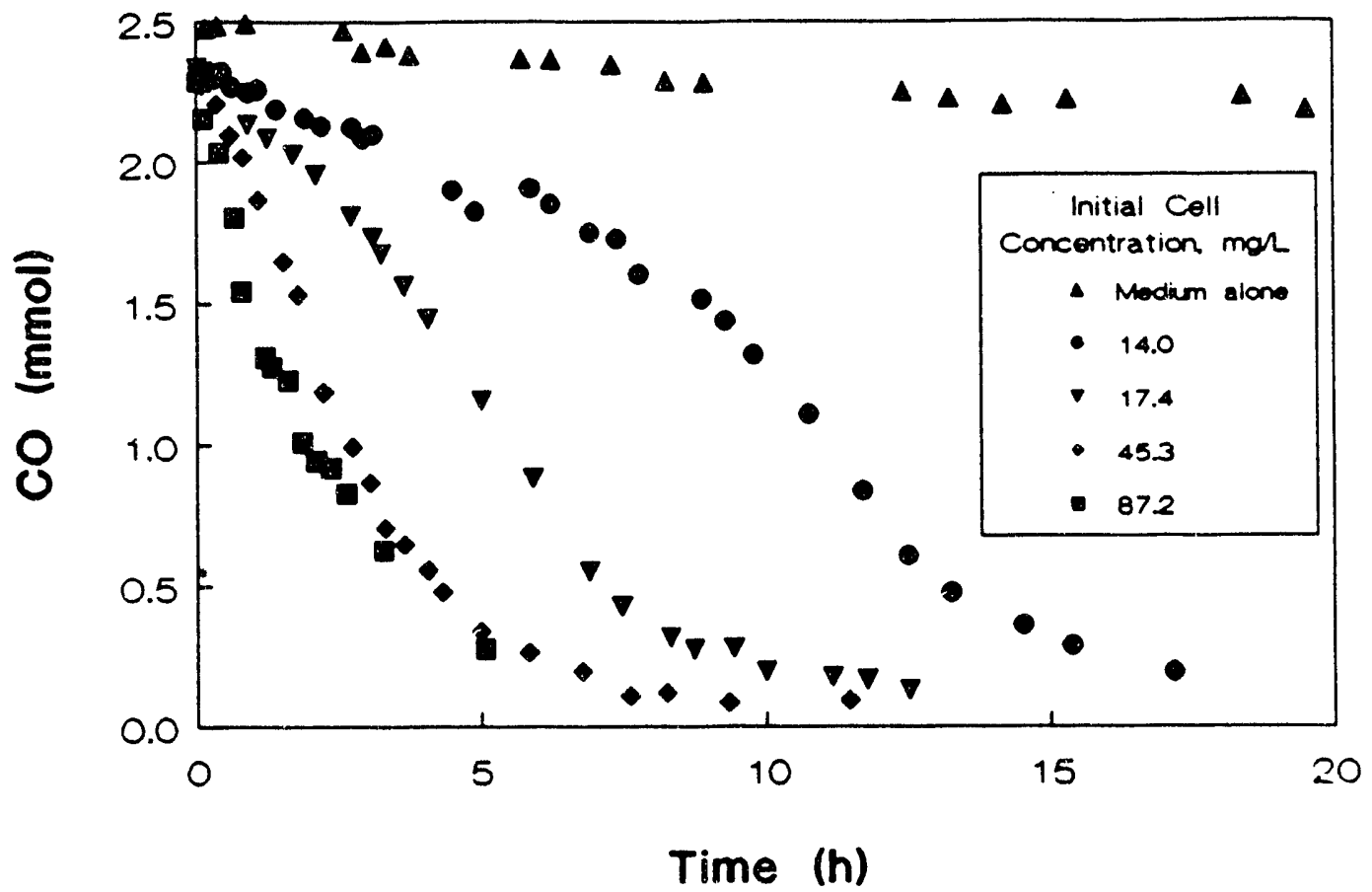

Figure 3.20 co uptake by $E$. limosum in the presence of COS. 


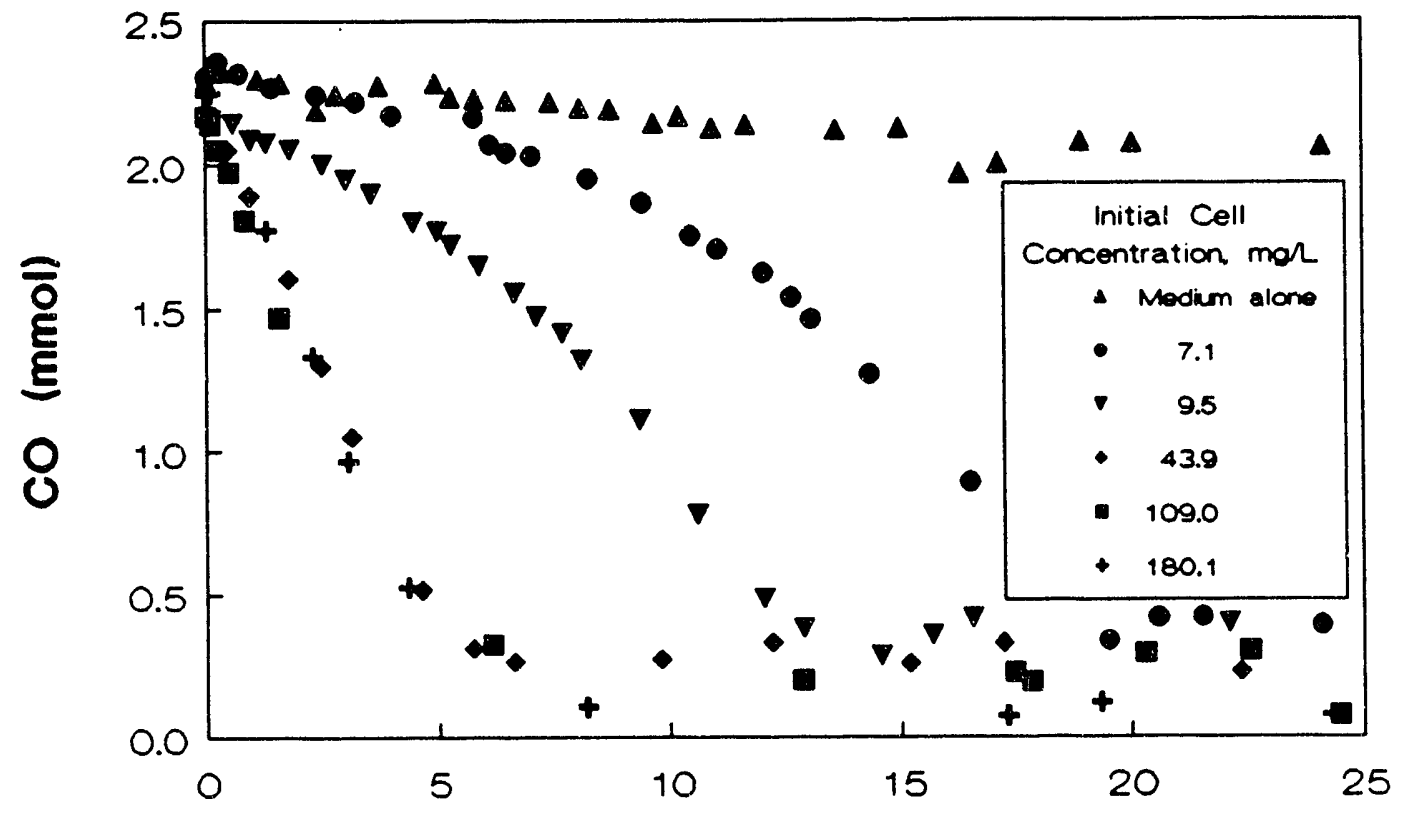

Time (h)

Figure 3.21 Co uptake by $C$. ljungdahlii in the presence of COS. 


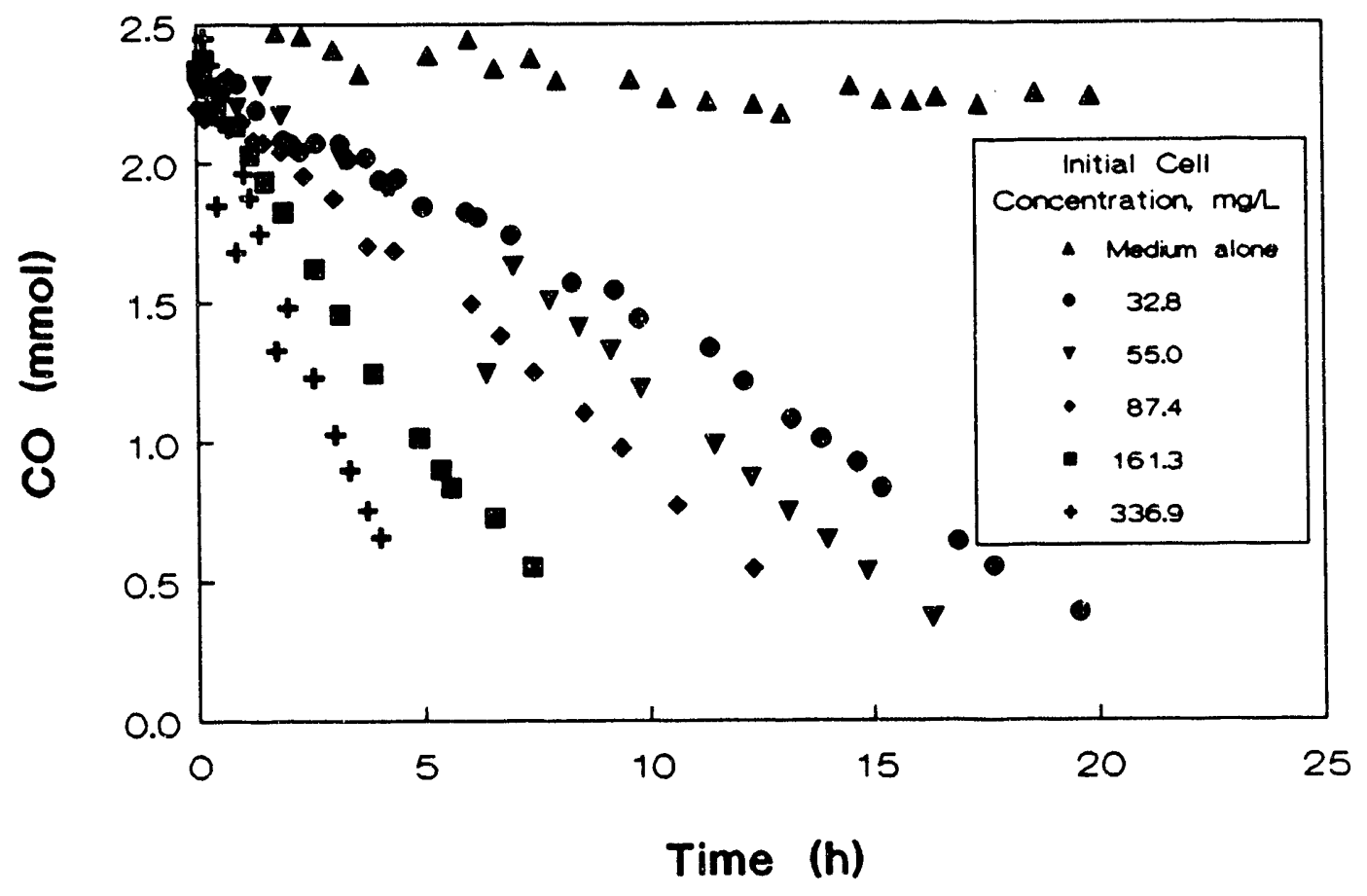

Figure 3.22 Co uptake by $R$. rubrum in the presence of COS. 


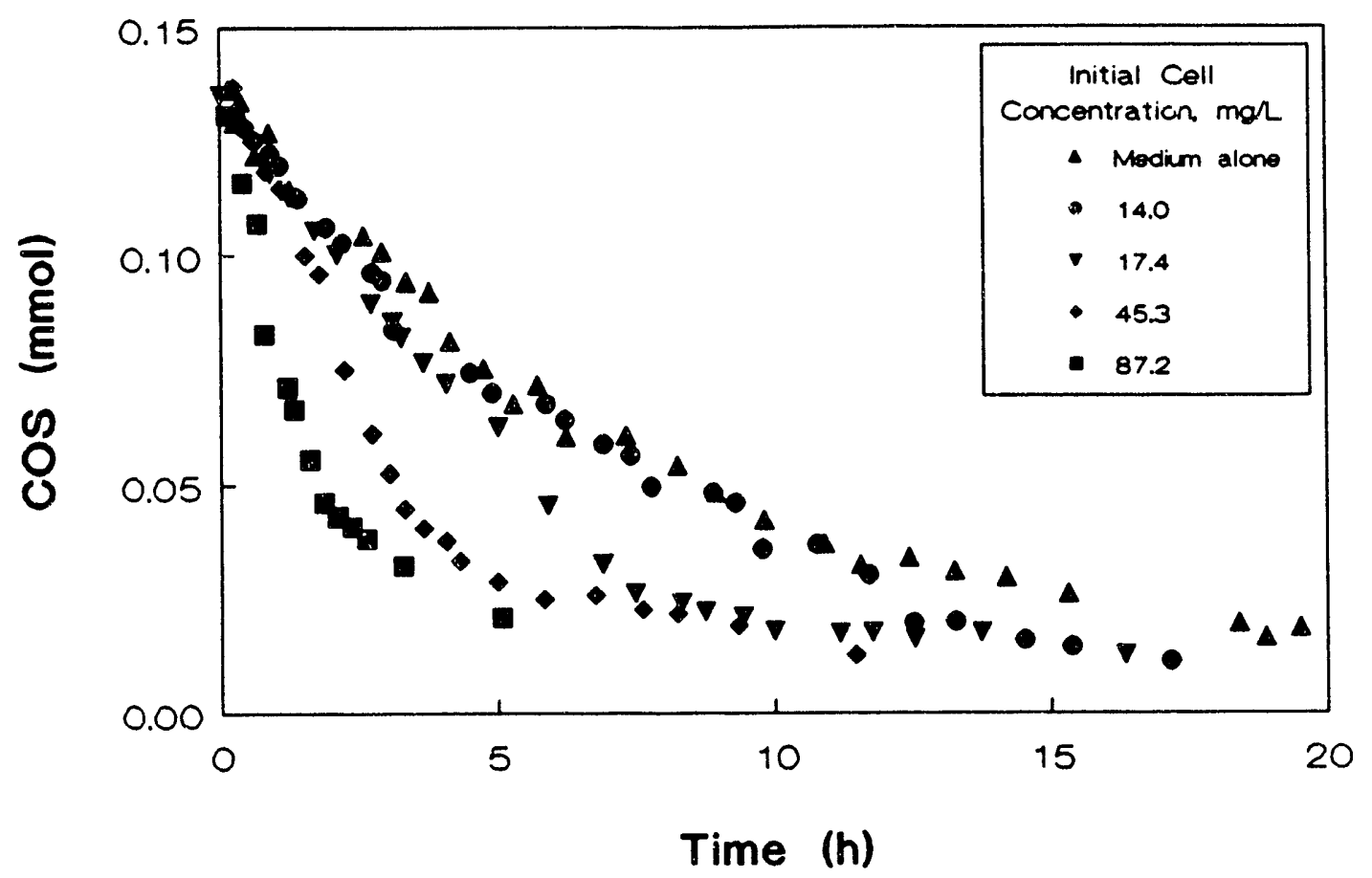

Figure $3.23 \mathrm{COS}$ degradation by $P$. productus in comparison to the medium alone. 


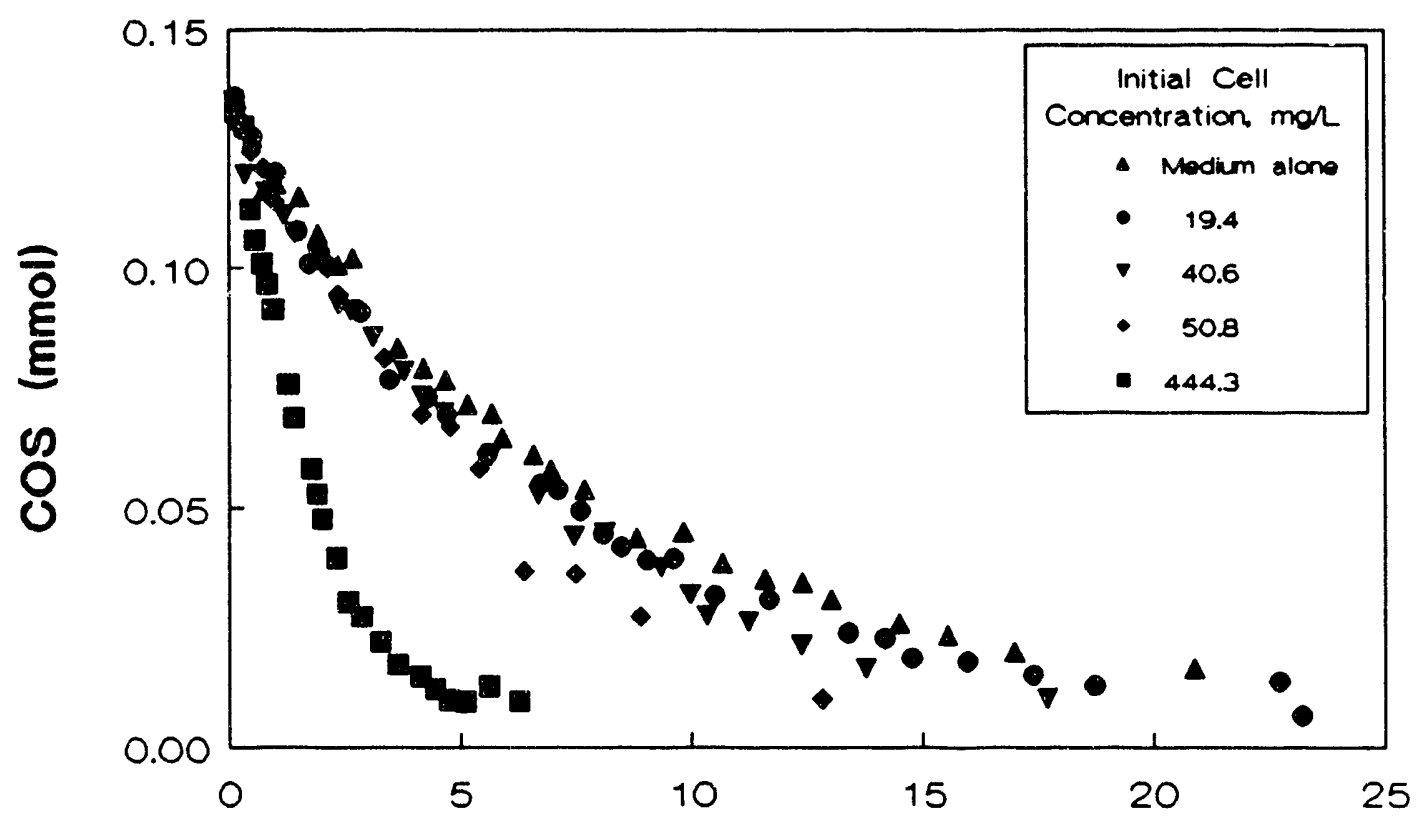

Time (h)

Figure 3.24 COS degradation by $E$. limosum in comparison to the medium alone. 


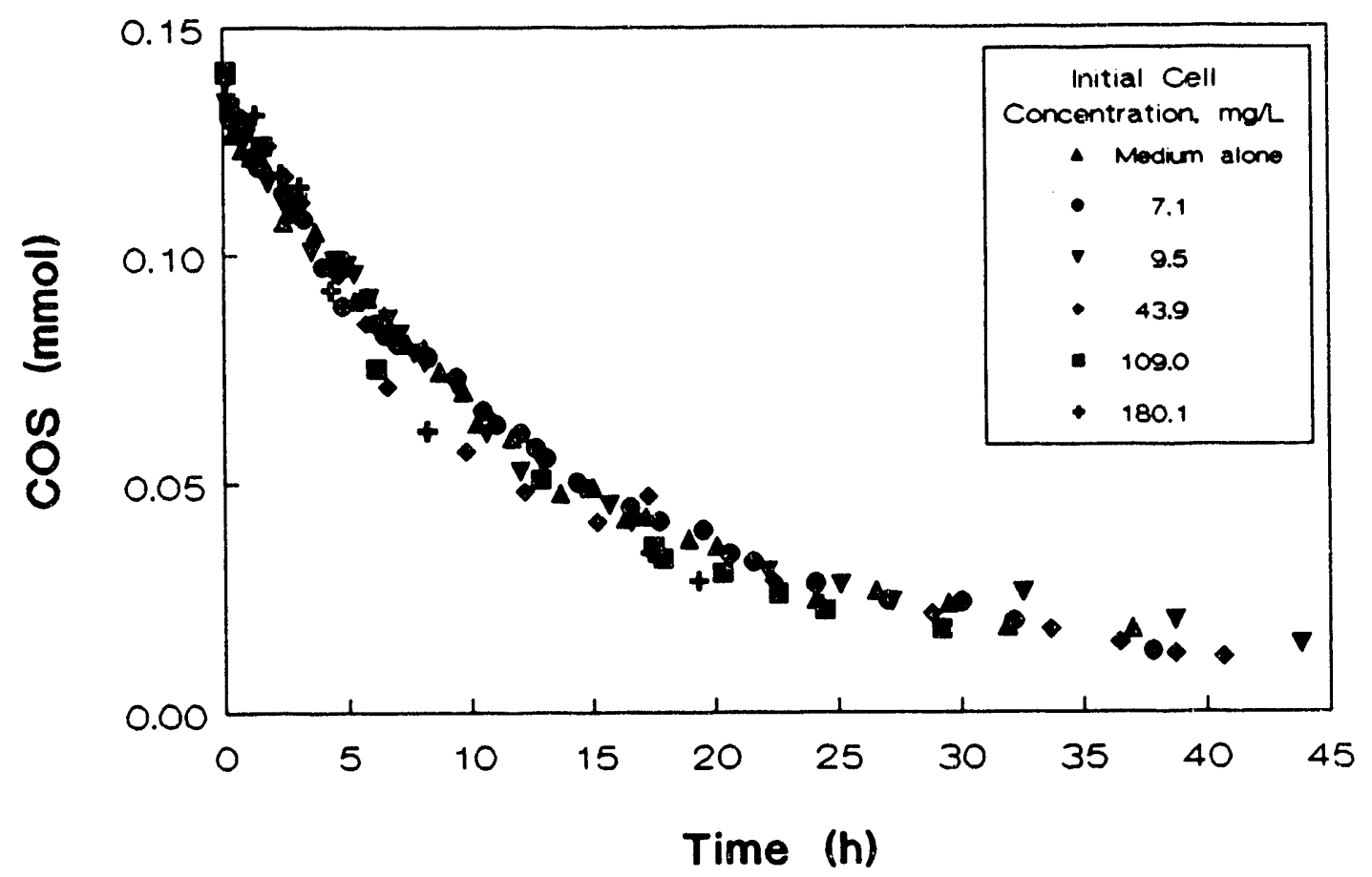

Figure $3.25 \mathrm{COS}$ degradation by $C$. ljungdablii in comparison to the medium alone. 


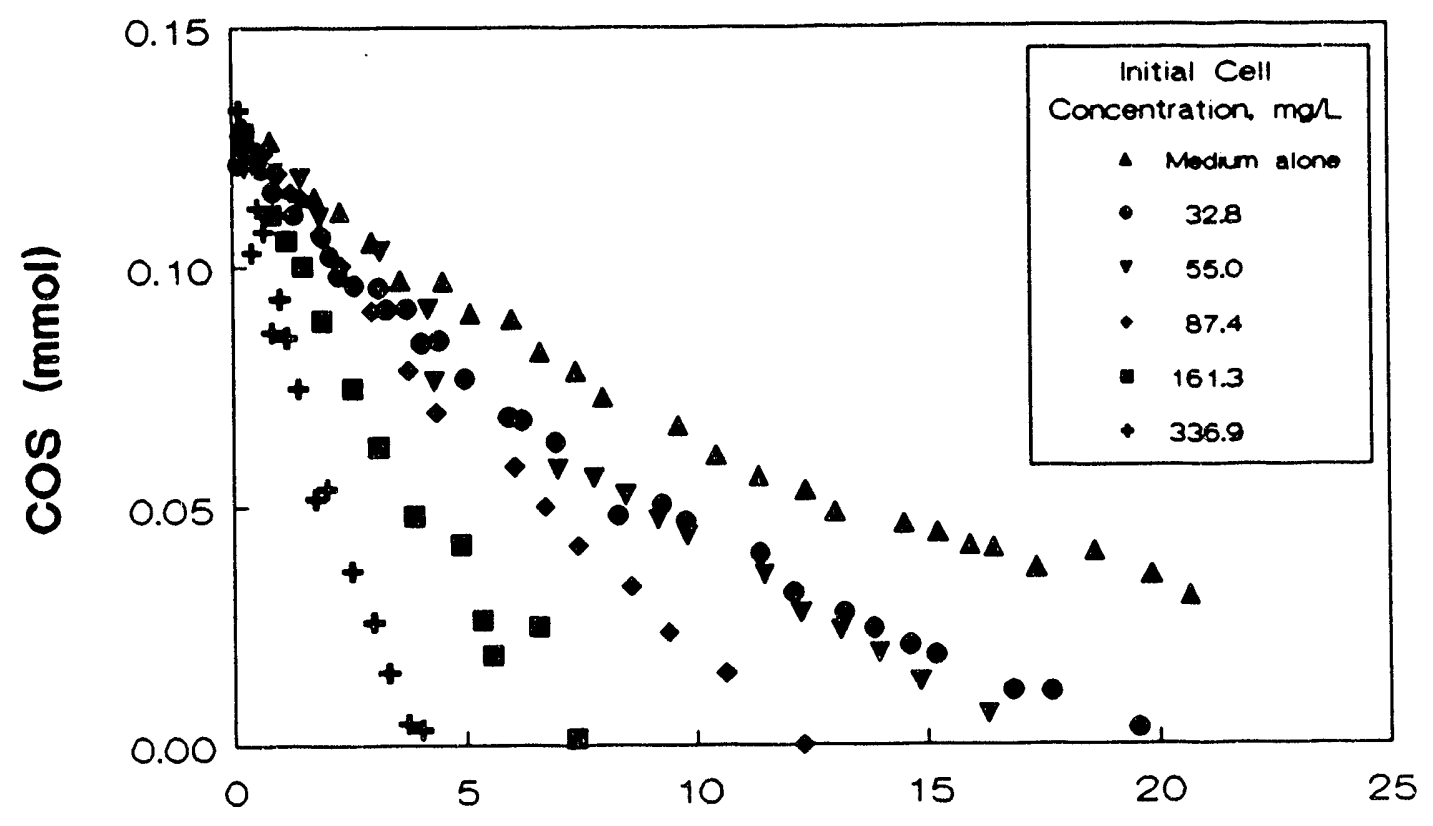

Time (h)

Figure 3.26 COS degradation by $R$. rubrum in comparison to the medium alone. 
used for experiments with $R$. rubrum.

In analyzing the results presented in Figures 3.19-3.26 it was noted from the slopes of the curves that the rate of $\cos$ degradation for $P$. productus and $E$. Iimosum tended to decrease when the concentrations of both $C O$ and $C O S$ were very low. It is possible that the rate of COS degradation could exhibit a corresponding decrease. If the difference in initial rates of cos degradation with cells and in medium alone is plotted as a function of the difference in Co uptake rates by the cells and in medium alone for $P$. productus, E. Iimosum, and $R$. rubrum, a nearly linear trend is observed (Figure 3.27). At leastsquares fit forced through the origin yields a slope of $0.055 \mathrm{~mol} \mathrm{COS} / \mathrm{mol} \mathrm{CO}$. This ratio of initial rates may be compared to the initial amounts of gases present, which were approximately $0.06 \mathrm{~mol} \mathrm{COs} / \mathrm{mol}$ CO in all experiments. This would indicate similar kinetic utilization modes for both $C O$ and $\operatorname{COS}$, with cos possibly being "used" in place of $C O$. However, since the initial ratios (mol COS/mol COS) were kept constant in all experiments and isotope labeling was not employed, this conclusion is speculative.

The results of this study support the hypothesis that several organisms that are capable of utilizing $C O$ are also capable of degrading CO-like compounds, such as COS. Three organisms, Peptostreptococcus productus, Rhodospirillum rubrum, and Eubacterium limosum, were shown to metabolize COS at rates much higher than that of the reaction of $\mathrm{COS}$ with $\mathrm{H}_{2} \mathrm{O}$. Clostridium ljungdahlii, on the other hand, was not found to have an ability to degrade $\operatorname{COS} . \mathrm{H}_{2} \mathrm{~S}$ was detected as a major gas-phase product, but stoichiometric product yields have not yet been determined. 


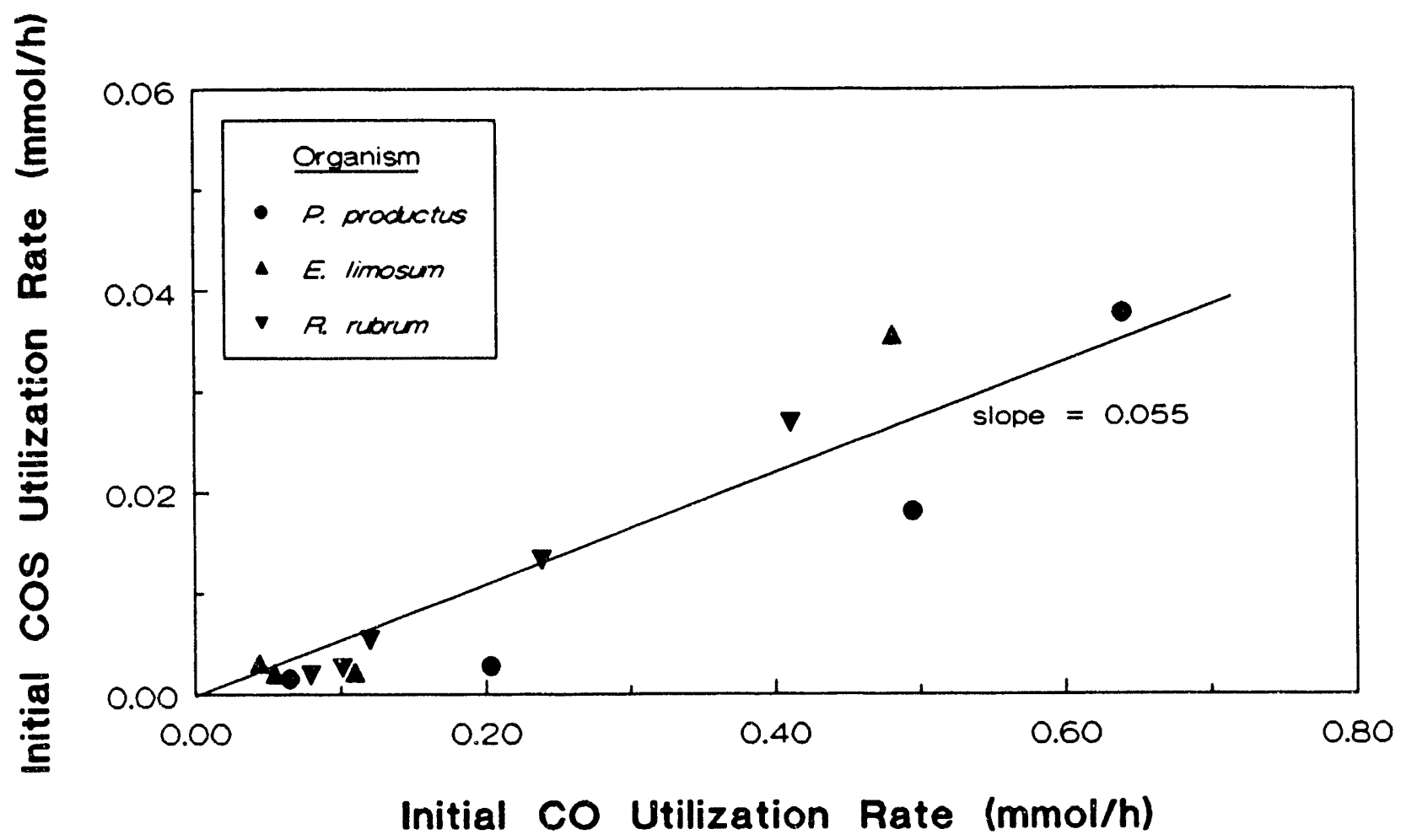

Figure 3.27 Initial COS-utilization rate as a function of initial Co-utilization rate for $P$. productus, Elimosum and $R$. rubrum. 
Cos degradation by $C$. ljungdahlii (see Figure 3.25) may have been limited by the low operating $\mathrm{pH}(\mathrm{pH} 5)$. In comparing the rates of cOS degradation by the medium alone, it seen that the rate (slope of curve) at $\mathrm{pH} 5$ is much lower than the rate at $\mathrm{pH} 7$. Perhaps $C$. Ijungdahlii would have shown the ability to degrade $\operatorname{COS}$ if an initial $\mathrm{pH}$ of 7.0 were utilized.

In any case, it has been demonstrated that $\operatorname{COS}$ can be degraded by some Co-utilizing organisms faster than in medium alone. Particularly effective was $R$. rubrum, which completely degraded the added $\cos$ in $<20 \mathrm{~h}$ for cell concentrations above $55 \mathrm{mg} / \mathrm{L}$. Possible mechanisms for degradation include, but are not limited to, dual substrate utilization of both $\cos$ and $c 0$. Studies to elucidate the reaction mechanism and microbial kinetics are in progress.

It was observed during the $\mathrm{COS}$ degradation studies that $\mathrm{H}_{2} \mathrm{~S}$ was a major product formed in the gas phase for each of the three bacteria capable of degrading $\cos$ (data not shown). No other gas-phase products were formed, and liquid-phase products were not detected or measured. Product yields in verifying process stoichiometry are under study.

\subsubsection{Indirect COS Utilization by Chlorobia}

COS undergoes a chemical reaction with water to produce $\mathrm{H}_{2} \mathrm{~S}$ and $\mathrm{CO}_{2}$ by the equation:

$$
\mathrm{COS}+\mathrm{H}_{2} \mathrm{O} \rightarrow \mathrm{CO}_{2}+\mathrm{H}_{2} \mathrm{~S}
$$

Thompson et al. (7) studied the reaction and showed that the kinetics of the reaction could be described by a first order irreversible rate expression over a temperature range of $15-40^{\circ} \mathrm{C}$. They showed that the rate constant varied with temperature by the equation:

$$
k=1.06 \times 10^{12} \text { e }^{-22710 / R^{\top} T}
$$


where $k$ is the first order rate constant, $\sec ^{-1}$;

$R$ is the ideal gas constant, $1.987 \mathrm{cal} / \mathrm{gmole}^{\circ} \mathrm{C}$; and

$\mathrm{T}$ is the absolute temperature, ${ }^{\circ} \mathrm{K}$.

At $37^{\circ} \mathrm{C}$, the rate constant is thus calculated as $0.37 \mathrm{~h}^{-1}$.

C. thiosulfatophilum can utilize COS indirectly, by utilizing the $\mathrm{H}_{2} \mathrm{~S}$ produced by the chemical reaction in Equation (3.2). If this is indeed a satisfactory process, it will eliminate the need for an additional organism (such as Rhodospirillum rubrum or Peptostreptococcus productus) for COS degradation.

4.0 CONCLUSIONS

Based upon the results of this culture screening study, $R$. rubrum is recommended for biocatalysis of the water gas shift reaction and $C$. thiosulfatophilum is recommended for $\mathrm{H}_{2} \mathrm{~S}$ conversion to elemental sulfur. Both bacteria require tungsten light for growth and can be co-cultured together if $\mathrm{H}_{2} \mathrm{~S}$ conversion is not complete (required concentration of at least $1 \mathrm{ppm}$ ), thereby presenting $\mathrm{H}_{2}$ uptake by $C$. thiosulfatophilum.

COS degradation may be accomplished by utilizing various co-utilizing bacteria or by indirectly converting $\operatorname{COS}$ to elemental sulfur after the COS first undergoes reaction to $\mathrm{H}_{2} \mathrm{~S}$ in water. The second alternative is probably preferred due to the low expected concentration of $\operatorname{COS}$ relative to $\mathrm{H}_{2} \mathrm{~S}$. 


\subsection{LITERATURE CITED}

1. M. P. Dashkevicz and R. L. Uffen, "Identification of a Carbon MonoxideMetabolizing Bacterium as a Strain of Rhodopseudomonas gelatinosa (Molisch) van Niel," Int. J. Sys. Bacteriol., 29(2), 145 (1979).

2. American Type Culture Collection, "Catalog of Bacteria and Phages," 17 th ed., American Type Culture Collection, Rockville, MD (1989).

3. "Bergey's Manual of Determinative Bacteriology," 8 th ed., Eds., R. E. Buchanan and N. E. Gibbons, The Williams \& Williams Company, pp. 26 (1974).

4. "Bergey's Manual of Determinative Bacteriology," 8 th ed., Eds., R. E. Buchanan and N. E. Gibbons, The Williams \& Williams Company, pp. 35, 51, 456 (1974).

5. J. F. Imhoff and H. G. Trüper, "Ectothiorhodospira abdelmalekii sp. nov., a New Halophilic and Alkaliphilic Phototropic Bacterium," Zbl. Bakt. Hyg., I. Abt. Orig. C2, 228 (1981).

6. M. T. Madigan and T. D. Brock, "Photosynthetic Sulfide Oxidation by Chloroflexus aurantiacus, a Filamentous, Photosynthetic, Gliding Bacterium," J. Bacteriol., 122, 782 (1975).

7. H. W. Thompson, C. F. Kearton and S. A. Lamb," The Kinetics of the Reaction Between Carbonyl Sulfide and Water," J. Chem. Soc., 1033 (1935).

8. M. J. McInezney, M. P. Bryant and N. Pfennig, "Anaerobic Bacterium that Degrades Fatty Acids in Syntrophic Association with Methanogens," Arci. Microbiol., 122, 129 (1979).

9. B. R. S. Genther, M. P. Davis and M. P. Bryant, "Features of Rumen and Sewage Sludge Strains of Eubacterium limosum, a Methanol-and $\mathrm{H}_{2}-\mathrm{CO}_{2}$ Utilizing Species," Appl. Environ. Microbiol., 42, 12 (1981).

10. K. T. Klasson et al., "Advanced Studies of the Biological Conversion of Coal Synthesis Gas to Methane," Final Report for Contract No. DE-AC2186MC23281 for Morgantown Energy Technology Center, p. 136, November 1989.

11. P. M. Vignais, A. Colbeau, J. C. Willison, and Y. Jouanneau, Advances in Microbial Physiology, 26, 155 (1985).

12. W. H. Lorowitz and M. P. Bryant, App1. Environ. Microbiol., 47, 961 (1984).

13. H. Gest and M. D. Kamen, J. Bacteriol., 58, 239 (1949). 
14. H. Gest and M. D. Kamen, Science, 109, 558 (1949).

15. J. M. Siegel and M. D. Kamen, J. Bacteriol., 61, 215 (1951).

16. P. Hillmer and H. Gest, J. Bacteriol., 129, 732 (1977).

17. K. Watanabe, J. S. Kim, K. Ho, L. Buranakarl, T. Kampee, and H. Takahashi, Agric. Biol. Chem., 45, 217 (1981).

18. B. A. Macler, R. A. Telroy, and J. A. Bassham, J. Bacteriol, 138, 446 (1979).

19. M. D. Ackerson, E. C. Clausen, and J. L. Gaddy, "Biological Conversion of Synthesis Gas," Quarterly Report No. 1-1, U. S. Department of Energy, Grant No. DE-FG21-90MC27225 (September-December 1990).

20. A. G. Eickmeyer and H. A. Gangriwala, Energy Progress, 1, 9-12, (1981).

21. L. S. Galstaun and R. F. Geosits, Energy Prog. 5, 156-160, (1985).

22. A. L. Kohl and F. C. Riesenfeld, Gas Purification, 4th ed., Gulf Publishing, Houston, TX (1985).

23. M. Caillet and A. Galerie, Ceram. 30, 171-194 (1980).

24. C. A. Euker, Jr., and R. D. Wessenhott, Energy Prog. 1, 12-16 (1981).

25. L. J. Kaplan, Chem. Eng., 89(6), 64-66 (1982).

26. J. T. Richardson, Hydro. Proc. 52(1), 91-95 (1973).

27. H. Jockel and B. E. Triebskorn, Hydro. Proc. 52(1), $93-98$ (1973).

28. K. D. Smith, K. T. Klasson, M. D. Ackerson, E. C. Clausen, and J. L. Gaddy, App1. Biochem. Biorechno1. 28/29, 787-796 (1991).

29. B. R. S. Genthner and M. P. Bryant, Appl. Environ. Microbiol. 43, 70-74 (1983).

30. J. L. Vega, K. T. Klasson, D. E. Kimmel, E. C. Clausen, and J. L. Gaddy, App1. Biochem. Biotechnol. 24/25, 329-340 (1990).

31. S. Barik, S. Prieto, S. B. Harrison, E. C. Clausen, and J. L. Gaddy, App1. Biochem. Biotechno1. 17/18, 363-378 (1988). 
32. J. L. Vega, S. Prieto, B. B. Elmore, E. C. Clausen, and J. L. Gaddy, App1. Biochem. Biotechno1. 20/21, 781-797 (1989).

33. L. M. Brown, MS thesis, University of Arkansas, Fayetteville, AR (1987).

34. K. T. Klasson, J. P. Cowger, C. W. Ko, J. L. Vega, E. C. Clausen, and J. L. Gaddy, Appl. Biochem Biotechnol. $\underline{4 / 25}, 317-328$ (1990). 

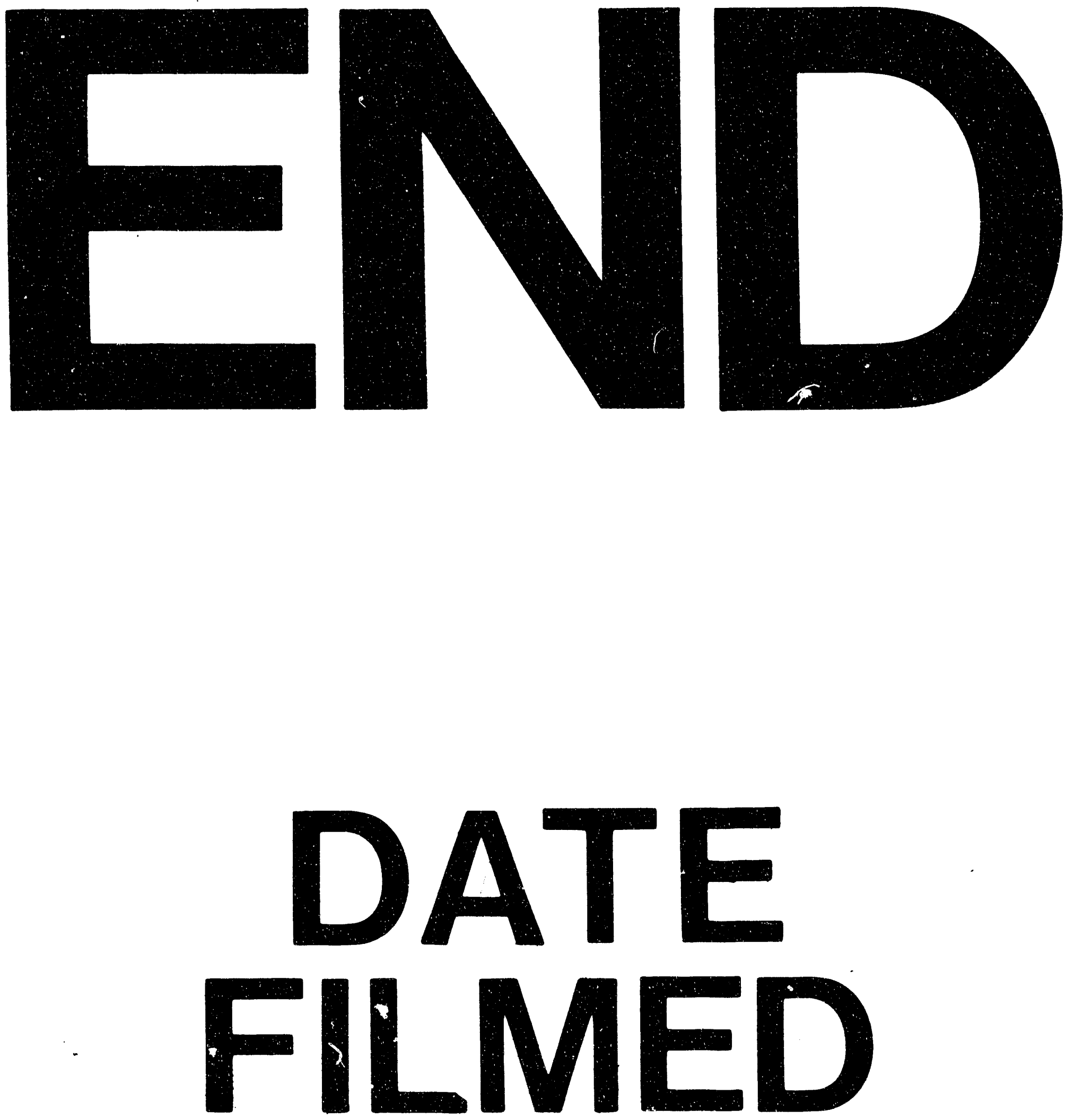

)

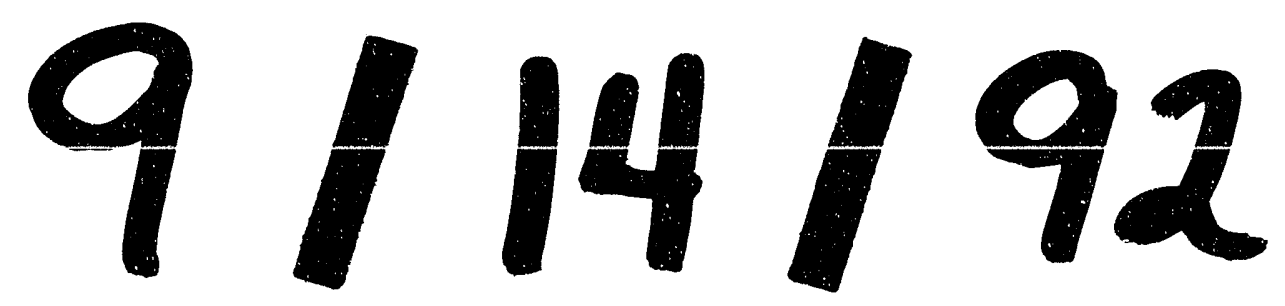


